\title{
The latest improvements with SURFEX v8.0 of the Safran-Isba-Modcou hydrometeorological model for France
}

\author{
Patrick Le Moigne $^{1}$, François Besson ${ }^{2}$, Eric Martin ${ }^{1,3}$, Julien Boé ${ }^{4}$, Aaron Boone ${ }^{1}$, Bertrand Decharme ${ }^{1}$, \\ Pierre Etchevers $^{2}$, Stéphanie Faroux ${ }^{1}$, Florence Habets ${ }^{5}$, Matthieu Lafaysse ${ }^{6}$, Delphine Leroux ${ }^{1}$, and \\ Fabienne Rousset-Regimbeau ${ }^{2}$ \\ ${ }^{1}$ CNRM, Université de Toulouse, Météo-France, CNRS, Toulouse, France \\ ${ }^{2}$ Direction de la Climatologie et des Services Climatiques, Météo-France, Toulouse, France \\ ${ }^{3}$ Irstea, Université d'Aix Marseille, RECOVER, Aix-en-Provence, France \\ ${ }^{4}$ CECI, Université de Toulouse, CERFACS, CNRS, Toulouse, France \\ ${ }^{5}$ CNRS UMR 8538, Laboratoire de Géologie, École Normale Supérieure, PSL Research University, \\ 24 rue Lhomond, 75005 Paris, France \\ ${ }^{6} \mathrm{CNRM}$, Université de Grenoble, Météo-France, CNRS, Grenoble, France
}

Correspondence: Patrick Le Moigne (patrick.lemoigne@meteo.fr)

Received: 30 January 2020 - Discussion started: 2 March 2020

Revised: 20 July 2020 - Accepted: 22 July 2020 - Published: 1 September 2020

\begin{abstract}
This paper describes the impact of the various changes made to the Safran-Isba-Modcou (SIM) hydrometeorological system and demonstrates that the new version of the model performs better than the previous one by making comparisons with observations of daily river flows and snow depths. SIM was developed and put into operational service at Météo-France in the early 2000s. The SIM application is dedicated to the monitoring of water resources and can therefore help in drought monitoring or flood risk forecasting on French territory. This complex system combines three models: SAFRAN, which analyses meteorological variables close to the surface, the ISBA land surface model, which aims to calculate surface fluxes at the interface with the atmosphere and ground variables, and finally MODCOU, a hydrogeological model which calculates river flows and changes in groundwater levels. The SIM model has been improved first by reducing the infrared radiation bias of SAFRAN and then by using the more advanced ISBA multi-layer surface diffusion scheme to have a more physical representation of surface and ground processes. In addition, more accurate and recent databases of vegetation, soil texture, and orography were used. Finally, in mountainous areas, a sub-grid orography representation using elevation bands was adopted, as was the possibility of adding a reservoir to represent the effect of aquifers in mountainous areas. The numerical simu-
\end{abstract}

lations carried out with the SIM model covered the period from 1958 to 2018, thereby providing an extensive historical analysis of the water resources over France.

\section{Introduction}

The coupling of hydrogeological models and land surface models (LSMs) aims to represent the water cycle by considering as many physical processes as possible. Thus, in LSMs, precipitation that reaches the ground contributes to water storage, evaporation, surface runoff, and infiltration into the soil. In addition to the water balance, LSMs simulate the surface energy balance, which is closely related to the water balance in terms of evaporation. In such a coupled system, surface runoff is collected by the surface river system, while deep infiltration of the soil contributes to aquifer recharge. Such systems have been used for decades to study water resources and predict their evolution. LSMs, whether coupled or not to hydrological models, have been the subject of numerous studies that have improved them over time and have led to a better description and understanding of the key processes governing exchanges at the interface between the surface and the atmosphere and the surface and the subsurface. These studies, which include international mea- 
surement campaigns or more regional and even local initiatives, have made it possible to evaluate surface models and even certain parameterizations by comparing simulation results with different types of observations such as in situ measurements, reanalyses, or satellite products. Simulations were carried out offline, i.e. decoupled from the atmosphere, to limit the impact of potential atmospheric biases in the surface schemes by constraining atmospheric forcing through observations when possible. The first international model intercomparison projects were the Project of Intercomparison of Land surface Parametrization Schemes (PILPS), described in Henderson-Sellers et al. (1996), which began with forcing from atmospheric simulations (Pitman et al., 1993) and, in a second stage, forcing from local observations (Chen et al., 1997). The successive phases also focused on different issues, such as snow and frost parameterization (Schlosser et al., 2000) and river flow assessment (Wood et al., 1998; Bowling et al., 2003). In the spirit of PILPS, GSWP (Global Soil Wetness Project; Dirmeyer, 2011) was initiated with global-scale simulations. The results of this project are the first global offline multi-model simulations of LSMs. Other more specific intercomparison projects have been carried out such as SnowMIP (Etchevers et al., 2004) to study snowrelated processes, ALMIP (Boone et al., 2009), focusing on critical surface processes in West Africa at the regional scale, and Rhône-AGGrégation (Boone et al., 2004) to study coupling with hydrology. More recently, the PLUMBER project (Best et al., 2015) has attempted to identify how LSMs behave in relation to certain benchmarks and to define performance criteria that LSMs should be able to achieve according to the information available in atmospheric forcing, thus avoiding direct comparison with observations.

In many of these intercomparison studies, the surface models were validated at the local scale and used average parameters that were known fairly accurately. However, these models sometimes have strongly non-linear components, such as the link between root zone moisture and transpiration when the soil dries out (Sellers et al., 1997), so it is necessary to develop sub-grid parameterizations to compensate for the lack of representativeness of the mean parameters. Overgaard et al. (2006) conducted a review of surface models based on energy balance that are used for hydrological purposes. They stressed the need to validate the models at the local scale, but also showed the interest of using remote sensing data to evaluate the models. Indeed, the validation of LSMs using river flows alone does not prove that surface fluxes, for example, are well simulated by the model and that there is no error compensation. Furthermore, estimating surface fluxes by remote sensing is not straightforward and requires certain assumptions that are not always valid, and inversion models are used to translate the remote sensing measurement into a model variable equivalent. However, using surface fluxes to validate surface models is also subject to questioning since the energy balance measured at the surface is generally not closed (Foken, 2008), whereas it is an imposed constraint in surface models. International measurement networks such as FLUXNET (El Mayaar et al., 2008; Napoly et al., 2017) are also widely used to evaluate surface models at the point scale. Remote sensing provides a means of observing hydrological state variables over large areas (Schmugge et al., 2002) and can be useful in the case of LSMs coupled to hydrological models, in particular in order to assess evaporation (Kalma et al., 2008; Long et al., 2014; Wang et al., 2015) or soil moisture (Goward et al., 2000; Albergel et al., 2012; Fang et al., 2016). It should be noted that these remote sensing data can be assimilated to correct the model state variables at the initial time and during the hindcast (Albergel et al., 2017).

In addition, climate models have been evaluated at both global and regional scales through hydrology. Indeed, the coupling between their land surface model and hydrology allows a quantitative assessment to be made through comparisons to variables such as river flow, groundwater levels, and snow depth. This is the case of river flows simulated by hydrogeological models, which can be compared with in situ measurements from gauging stations (Habets et al., 2008; Decharme et al., 2013; Alkama et al., 2010; Barthel and Banzhaf, 2015; Decharme et al., 2019). The coupling between LSMs and hydrogeological models in water resource studies is an appropriate tool for answering scientific questions such as the importance of climate change for these resources (Vidal et al., 2010; Dayon et al., 2018; Bonnet et al., 2017) or how human activity influences these resources (Martin et al., 2016; Biancamaria et al., 2019). Recent initiatives to study the impact of anthropization on water availability, such as those supported by the Global Energy and Water Exchanges (GEWEX) project (Harding et al., 2015) wherein the contribution of LSMs to modelling appears to be important, show that irrigation needs to be considered in the models (Boone et al., 2019).

At Météo-France, the Safran-Isba-Modcou (SIM) system was first designed to study the water cycle in major French basins such as the Rhône basin (Etchevers et al., 2000), the Adour basin (Habets et al., 1998), the Garonne basin (Voirin et al., 2001), and finally all of France (Habets et al., 2008). This system has been shown to be very useful for many applications. For example, since 2003, the SIM system has been used operationally at Météo-France for drought monitoring; this is done using hindcast simulations in addition to nearreal-time applications. These applications in France were based on an LSM using the force-restore approach (Noilhan and Planton, 1989; Noilhan and Mahfouf, 1996) for heat and water transfer in the soil. However, this method has some limitations in terms of the realism of certain physical parameterizations, which are detailed in Sect. 2.2. These limitations concern the representation of snow, the interactions between snow and ground freezing, which are not always well represented, the description of the vertical profile of roots in the soil, and the composite approach to represent vegetation, which mixes different types of vegetation into one with aggregated characteristics. Although this method has proven, 
over the last decades, to be suitable for addressing scientific issues related to water resources, a more physical approach, based on the diffusion of heat and moisture in the soil (Decharme et al., 2011), has been developed to consider more sophisticated numerical schemes and improve system performance.

The objective of this paper is to show how the development of new parameterizations and better atmospheric forcing prescriptions have improved the performance of the system. The current study, based on numerical simulations covering the period 1958-2018, shows how improvements in atmospheric forcing, land surface model physics, and sub-grid orography and hydrology improve the modelled river flow and snow depth of the SIM system. It also aims to describe how the model results are affected by each change separately and finally to demonstrate that the new model configuration performs better than the previous one in terms of river flow extremes, as well as when simulated snow depth or average river flow is compared to observed data.

Section 2 describes the original SIM configuration and its recent updates. Section 3 presents climate data and evaluation datasets, as well as the offline experiments used to demonstrate the advantages of the new SIM system. In Sect. 4 the results of the new system are presented, and finally they are discussed in the last section.

\section{SIM hydrometeorological model}

\subsection{Overview of the 2008 version of the model}

The SIM hydrometeorological model (Habets et al., 2008) combines the three models: SAFRAN, ISBA, and MODCOU. SAFRAN (Durand et al., 1993; Quintana Seguí et al., 2008) performs a 6-hourly analysis of near-surface meteorological variables such as temperature and relative humidity at $2 \mathrm{~m}$, wind speed, cloud cover, and a daily analysis of $24 \mathrm{~h}$ accumulated precipitation. The analysis is carried out over geographical areas covering a few hundred square kilometres (Le Moigne, 2002), and the analysed fields are interpolated to hourly time steps. Direct and diffuse solar radiation and infrared radiation are calculated from the analysis of cloud, temperature, and humidity profiles using a radiative transfer model (Ritter and Geleyn, 1992). A spatial interpolation is then performed on a regular horizontal $8 \mathrm{~km}$ grid to provide the ISBA land surface model (Noilhan and Planton, 1989; Noilhan and Mahfouf, 1996) with the necessary climate information. The grid is composed of 9892 cells (Fig. 1a) covering France and is extended beyond the borders to include the upstream part of the catchment basins.

The ISBA model uses SAFRAN analysis as input and calculates the surface energy and water budgets over the vegetated areas. The water budget in ISBA ensures that soil moisture results from the balance between water input from incoming precipitation and water losses due to surface evap- oration, surface runoff, and infiltration into the soil. These last two components are fed into the hydrogeological model MODCOU (Ledoux et al., 1989; Habets et al., 1998) in order to calculate the temporal evolution of river flows for a given set of gauging stations and groundwater heads where aquifers are simulated, i.e. on the Seine and Rhône basins only (delimited by the yellow zones in Fig. 1b). The original SIM system differs in many respects from the version described in this document.

\subsection{Improvements to the land surface model in SURFEX v8.0}

In the original SIM system, heat and water transfers in the soil were based on the force-restore method (Noilhan and Planton, 1989; Noilhan and Mahfouf, 1996; Decharme et al., 2011), which has been widely used in research for decades and is still operationally used in the French global numerical weather prediction model ARPEGE (Courtier and Geleyn, 1988) and the mesoscale model AROME (Seity et al., 2011). In the force-restore method, the soil is divided into two layers for temperature and three layers for moisture (Boone et al., 1999). However, such a method has shown some limitations in the representation of surface and soil processes such as the interaction between snow and soil freezing (Luo et al., 2003) due to vertical discretization and the inability to correctly represent the vertical profile of roots in the soil (Braud et al., 2005) and thus the vertical transfers of moisture and heat. The alternative to using the force-restore method was developed by Boone et al. (1999) and revisited by Decharme et al. (2011), who proposed using diffusive equations to solve both heat and water transfer equations in the soil based on Fourier and Darcy laws, respectively. Such a method proposes a discretization of the soil into 14 layers, resulting in a total depth of $12 \mathrm{~m}$, with a fine description of the subsurface layers to capture the diurnal cycle. The vertical discretization (bottom depth of each layer in metres) is as follows: 0.01, $0.04,0.1,0.2,0.4,0.6,0.8,1,1.5,2,3,5,8$, and $12 \mathrm{~m}$, as described in Decharme et al. (2013). Heat transfer is resolved over the total depth, while moisture transfer is resolved only over the depth of the roots, which depends on the type of vegetation and its geographical location: a maximum of $1.5 \mathrm{~m}$ for type $\mathrm{C}_{3}$ crops and $2.5 \mathrm{~m}$ for forests in France. In such a model, soil temperatures and soil moisture are calculated at the same nodes, which is necessary to correctly represent soil freezing, for example. Another notable improvement concerns snow modelling. The original three-layer snow scheme developed by Boone and Etchevers (2001) aimed to represent the physical processes in the snow realistically with a simple model, and for this purpose some processes had been adapted from the Crocus snow model (Vionnet et al., 2012) for snow avalanche forecasting. The main new features recently developed and introduced into the ISBA snow model are described in detail in Decharme et al. (2016) and concern (i) snow stratification with an increase in the number of 

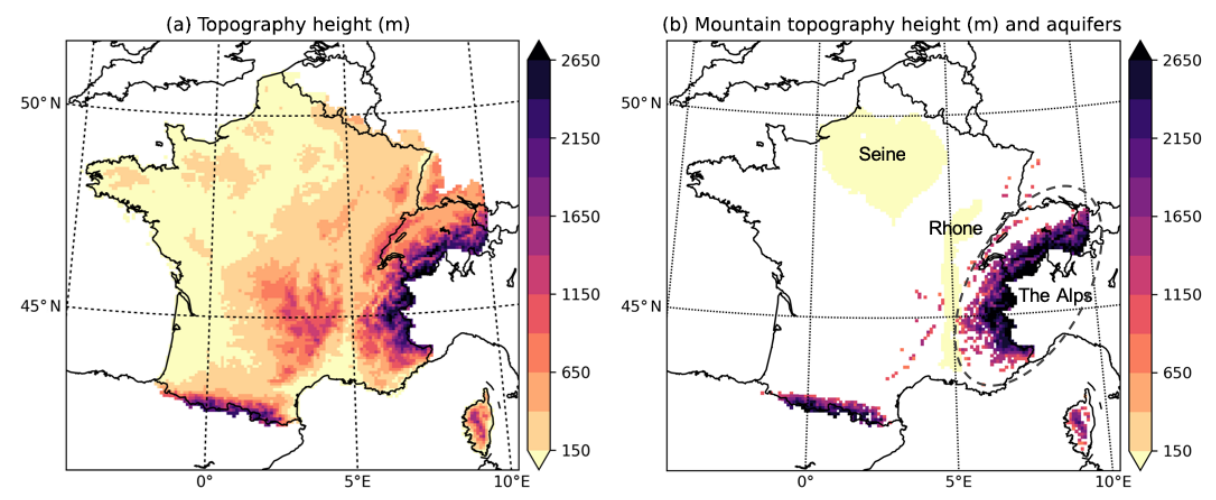

Figure 1. Height of the topography of the 9892 cells of the SIM grid (a) and the 3878 cells of the mountain SIM grid (b). The cells of the mountain grid correspond to the 1044 points having an altitude greater than $500 \mathrm{~m}$ and described vertically by several layers. Zones in yellow correspond to the Seine and Rhône aquifers. The dotted line delimits the Alps.

layers close to the surface in contact with the air, but also with the ground to better represent the diurnal cycle and heat transfer at the interface with the air and ground, respectively, (ii) snow compaction due to changes in viscosity (Brun et al., 1989) and wind-driven densification at the surface (Brun et al., 1997), and (iii) snow absorption of solar radiation as a function of three-band spectral albedo.

Then, the representation of vegetation in the model has also evolved from the original version, wherein vegetation types within a grid cell were aggregated with averaged surface parameters (Noilhan and Lacarrere, 1995), whereas the new system uses 12 separate vegetation types, each with its own set of parameters (Masson et al., 2003; Faroux et al., 2013). The classification distinguishes three non-vegetated types (rocks, bare soil, and permanent snow and ice) and nine vegetated types: temperate deciduous forest, boreal conifers, tropical conifers, $\mathrm{C}_{3}$ crops, $\mathrm{C}_{4}$ crops, irrigated crops, grasslands, tropical meadows, and peatlands, parks, and gardens. Although this approach is more computationally timeintensive because the model must be run for each vegetation type, the realism of ISBA simulations is increased because the parameters better characterize the contrasting surface properties. In addition, the explicit use of 12 vegetation types is mandatory when using ISBA-A-gs, the simplified photosynthesis module of ISBA (Calvet et al., 1998) aimed at representing a realistic photosynthesis of the different biomes. In the new version, the drought avoidance or drought tolerance response is adopted (Calvet et al., 2004).

Hydrological processes are obviously important in a system for calculating the water budget of natural surfaces and simulating river flows. The old parameterization of drainage, developed by Mahfouf and Noilhan (1996) for the forcerestore scheme, has been replaced by a method of diffusing water into the soil. In ISBA, surface runoff occurs over saturated areas (Dunne and Black, 1970). Habets et al. (1998) proposed sub-grid parameterization to generate surface runoff over grids of several square kilometres before the entire grid is saturated, in order to consider some re- gional heterogeneities in infiltration arising from orographic variability or precipitation spatial inhomogeneity. In this approach based on the sub-grid variability of topography used in the VIC model (Liang et al., 1994; Dümenil and Todini, 1992), the fraction of the saturated zone varies as a function of the water content of the soil and a curvature term $b$ that must be calibrated. In the original system $b$ is equal to 0.5 , a very high value compared to other studies at the watershed scale. Indeed, a more realistic value should be around 0.2 (Lohmann et al., 1998; Ducharne et al., 1998). However, the force-restore scheme is known to be too dry in terms of soil moisture (Decharme et al., 2011, 2019), and a steep slope (therefore a fairly large curvature term) in the grid mesh is required to generate sufficient runoff in certain regions. The use of the diffusion scheme has removed this constraint of a high $b$ factor, and in the new SIM application, a value of 0.25 is now used on zones without aquifers for which it is set at 0.01 corresponding to the absence of subgrid runoff. Dümenil and Todini (1992) have parameterized the fraction of saturated zone $A$ as a function of soil moisture $A\left(w_{2}\right)=1-\left(1-\frac{w_{2}}{w_{\text {sat }}}\right)^{b /(b+1)}$, where $w_{2}$ is the volumetric water content of the soil in the rooting zone and $w_{\text {sat }}$ its value at saturation. For a loamy zone $\left(w_{\text {sat }}=0.45 \mathrm{~m}^{3} \mathrm{~m}^{-3}\right)$ of wet soil $\left(w_{2}=0.4 \mathrm{~m}^{3} \mathrm{~m}^{-3}\right)$, the presence of an aquifer $(b=0.01)$ is characterized by a small area of saturated fraction of about $2 \%$.

\subsection{Use of more precise parameters for the land surface}

In addition to the changes in model physics described above, the land cover and topography databases have been updated to improve the realism of the external parameters of the ISBA model. The hydrogeological database representing the aquifer and the routing network was unchanged. In addition, the soil texture database for France is unchanged. In the former SIM system, the soil texture was based on a soil map provided by the Institut National de Recherches Agronomiques 
(INRA - King et al., 1995) at a resolution of $1 \mathrm{~km}$. In the new SIM system, texture is defined by the Harmonized World Soil Database (HWSD - Nachtergaele et al., 2012), which is a soil map at $1 \mathrm{~km}$ resolution that combines several datasets available worldwide. In particular for France, the INRA soil map mentioned above has been integrated into the HWSD dataset (used in other applications of SURFEX outside France), so this change does not affect the SIM simulations.

The topography, derived from $30 \mathrm{arcsec}$ global elevation data (GTOPO30, http://eros.usgs.gov/\{\#\}/Find_Data/ Products_and_Data_Available/gtopo30_info, last access: August 2020), has been replaced by that of the Shuttle Radar Topography Mission (SRTM90, https://cgiarcsi.community/ data/srtm-90m-digital-elevation-database-v4-1/, last access: October 2011) at a $90 \mathrm{~m}$ resolution (Fig. 1a). Note that in practice the impact of using SRTM90 is rather limited because the target grid resolution for SIM applications over France is $8 \mathrm{~km}$, which implies that small-scale differences between the orography data are averaged at such a resolution (thus the SIM topography is similar, whether GTOPO30 or SRTM90 is used).

The last modification of the input database is the vegetation map, which provides the fraction of each ecosystem. The global $1 \mathrm{~km}$ resolution map ECOCLIMAP1 (Masson et al., 2003) was originally used in the SIM application for France. Subsequently, a new classification algorithm was developed over Europe, the ECOCLIMAP2 land use map (Faroux et al., 2013), in order to use more accurate and recent satellite information as input for a longer period. Among the differences to note, ECOCLIMAP1 used, for example, AVHRR satellite data for 1992-1993, whereas ECOCLIMAP2 uses SPOT/VEGETATION data for 1999-2005. The impacts of modifying the vegetation fraction input to the ISBA model are multiple and will not be described here in detail (for a detailed comparison, see Faroux et al., 2013). ECOCLIMAP2 has definite advantages, the effects of which are directly reflected in the ISBA model. For example, ECOCLIMAP2 covers a longer time period than the previous version and therefore allows a better representation of the variability of surface parameters. Also, it distinguishes different types of crops that can be modelled separately, and therefore more accurately, with ISBA. The sensor onboard satellites have better accuracy and the uncertainty of the measurement is reduced. The vegetation fraction in particular is improved and with it the roughness length of the vegetation, which impacts the surface wind by the obstacle effect on near-surface flows. The leaf area index is also improved, and its increase leads to a better description of the evaporative fraction, which is key for the energy partitioning in the model. The more realistic surface albedo developed by Carrer et al. (2014) was also used, as Decharme et al. (2013) showed that it improved results at the global scale.

\subsection{Evolution of downward infrared radiation}

SAFRAN radiation has been corrected to compensate for a radiation deficit already identified in several studies (Le Moigne et al., 2002; Carrer et al., 2012; Decharme et al., 2013), although observations of this variable are very rare. Radiation in SAFRAN is simulated (Ritter and Geleyn, 1992) from an analysis of cloud cover based on analyses of temperature and humidity profiles from the French global atmospheric model ARPEGE. Le Moigne (2002) and Carrer et al. (2012) showed that SAFRAN's infrared radiation was weakly biased, and Decharme et al. (2013) increased overall infrared radiation over France by $5 \%$ in their offline simulations. The bias is likely due to a problem in the analysis and in the radiative transfer (RT) model. The cloud cover analysis is computed using temperature and humidity profiles from a large-scale atmospheric model that contains biases. Moreover, the model used to solve the RT is an old model with a rather low vertical resolution and is therefore probably suboptimal, but it was state of the art in the 1990s. For example, Le Moigne (2002) showed that infrared and solar radiation were too low at the Col de Porte site in the Alps and proposed a correction for cloud cover and altitude which was successfully applied to the Rhône basin in the RhôneAGG intercomparison experiment (Boone et al., 2004). In this study, only the infrared correction is considered and applied over the whole French territory. The infrared correction, described in Appendix A, was established by comparing the SAFRAN analysis and the infrared measurements of two meteorological stations, Carpentras and Col de Porte, which are reference stations for infrared measurements monitored by Météo-France located in the south-east of France and in the Alps, respectively. Carpentras is located in the plains, while Col de Porte, an experimental measurement site of the Centre d'Etudes de la Neige, is located in the French Alps at an altitude of $1340 \mathrm{~m}$ (Morin et al., 2012; Lejeune et al., 2018). The correction is only applied below $1340 \mathrm{~m}$, as a positive bias is found at the Saint-Sorlin site (Quéno et al., 2020). Figure 2 shows the annual average over the 60-year period for initial infrared radiation (panel a) and the amount of energy supplied when the correction is applied (panel b).

\subsection{Altitudinal sub-grid variability in mountainous areas}

In SAFRAN, the analysis is performed on homogeneous zones of several hundred square kilometres, and the vertical component is explicitly considered with a $300 \mathrm{~m}$ slicing along the vertical. For each grid cell $i$, the analysed variables $X^{\mathrm{a}}(i)$ are then interpolated on an $8 \mathrm{~km}$ horizontal grid, considering the average altitude of each grid cell. The analysed variables are then used as input to the ISBA surface model. At this resolution, the 9892 grids cover all of France and some border areas for hydrological purposes. However, this resolution is still too coarse to accurately capture the 

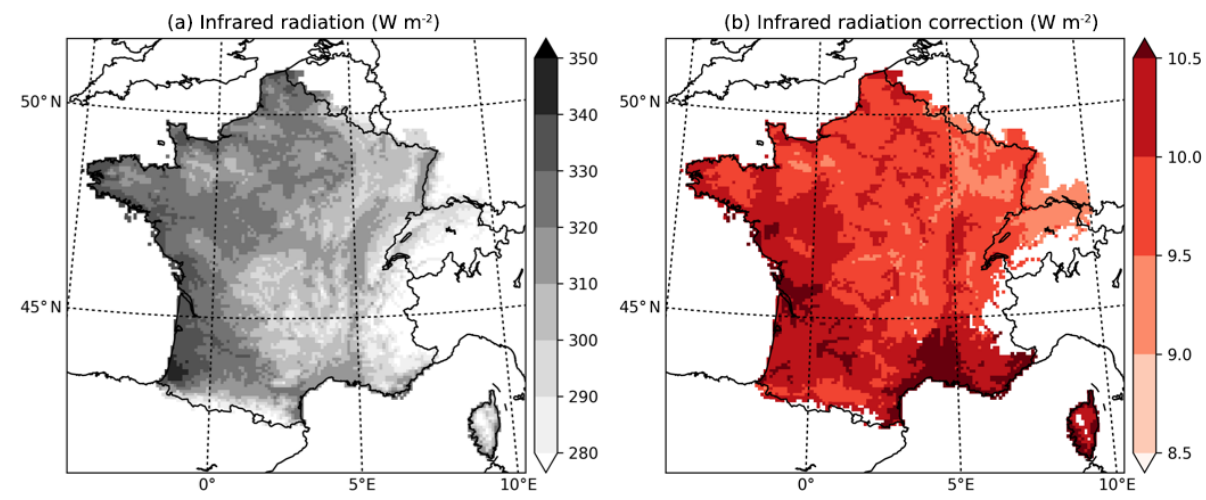

Figure 2. Annual average of uncorrected (a) and corrected (b) downward longwave infrared radiation from SAFRAN analysis.

variability of certain variables, particularly in the mountains. Lafaysse et al. (2011) demonstrated in the Durance basin that the use of altitude bands was an efficient method to better describe the spatial variability of the snow cover and its impacts on river flows at a numerical cost much lower than increasing the horizontal resolution. A similar approach was therefore defined for the entire French territory and can be summarized as follows: for a given mesh $i$, the SAFRAN analysis is performed every $300 \mathrm{~m}$ and $X^{\mathrm{a}}(i, k)$ represents the $k$ sets of analysed variables corresponding to each of the $k$ altitude bands. For each $i$, if the vertical sub-grid variability is sufficiently large, a complementary set of $k^{\prime}$ elevation bands is defined for different elevations in order to represent this variability. Vertical interpolation is then performed on the atmospheric forcing at each $k^{\prime}$ band. For each $k^{\prime}$ band, ISBA simulates surface runoff and soil infiltration, which are used to calculate the total surface runoff and soil infiltration for grid point $i$. Of the 9892 grid points, 1044 are above $500 \mathrm{~m}$ and have a high variability in sub-grid topography. Using a vertical discretization of $300 \mathrm{~m}$ at each grid point to represent topographic variability was ideal but too costly. A solution based on the distribution of elevations in each grid cell into five bands represented by the quintiles q20, q40, q60, and q80 was adopted. For each of the 1044 grid points, the vertical discretization varies spatially, and the irregular vertical mesh ranges from $23 \mathrm{~m}$ in medium mountains to $986 \mathrm{~m}$ in high mountains. Figure 1 (panel b) shows the elevation of the 1044 grid points at which the elevation band method is applied.

In addition, to compensate for the inability of the SIM system to simulate low flows when aquifers are not explicitly considered, sub-grid drainage parameterization was used in the original SIM system. This sub-grid drainage is controlled by a parameter calibrated for both lowland and mountain areas, but such a calibration does not work very well because the water used to support low flows is taken from the rooting zone and not from the aquifer. In the new system, this parameterization is removed, and a parameterization has been added to mimic the behaviour of a deep reservoir to sup- port low flows and to limit peak flooding due to snowmelt (Lafaysse et al., 2011). Retaining water due to snowmelt and releasing it during the dry season made it possible to simulate peak flooding, but summer low flows are still underestimated.

\section{Design of experiments and datasets}

\subsection{Offline simulations}

The SIM system is an offline application whereby the ISBA land surface model is driven by climate data and there is no feedback from the surface to the atmosphere. Different SIM configurations were designed to highlight the improvements achieved, with each simulation being equilibrated using a 2year spin-up.

The first configuration refers to the old SIM system (SIM_REF below, as described in Sect. 2.1), i.e. before any changes described above. An additional reference simulation (SIM_REF2 below) is based on SIM_REF wherein sub-grid drainage is removed. The first experiment (SIM_PHY hereafter) consists of modifying the physics and input databases. SIM_PHY uses the diffusion scheme with 14 layers in the soil, the improved snow scheme with 12 layers, a tile approach based on 12 vegetation types, and a runoff parameterization wherein the high constraint on the coefficient $b(b=$ 0.5 in the runoff parameterization in SIM_REF) has been lowered to 0.25. Also, in SIM_PHY, updated databases are used for a better representation of soil texture, orography, and vegetation. The correction of SAFRAN infrared radiation according to cloud cover is then introduced in the SIM_FRC experiment (based on SIM_PHY). Then SIM_TOP (based on SIM_FRC) uses the representation of sub-grid orography in mountains, and finally SIM_NEW (based on SIM_TOP) considers a drainage reservoir in mountains. Table 1 summarizes the main characteristics of the experiments.

In the SIM system, climatic data are provided by the SAFRAN analysis. In this study, SAFRAN covers a 60-year period, from 1 August 1958 to 31 July 2018. In SAFRAN, the guess of the analysis used is ERA-40 until 2002 and the 
Table 1. Main characteristics and differences in experiments.

\begin{tabular}{|c|c|c|c|c|c|c|}
\hline & SIM_REF & SIM_REF2 & SIM_PHY & SIM_FRC & SIM_TOP & SIM_NEW \\
\hline \multicolumn{7}{|l|}{ Land surface model } \\
\hline Soil transfers & Force-restore & Force-restore & \multicolumn{4}{|c|}{ Diffusion } \\
\hline Soil layers & 2 or 3 & 2 or 3 & \multicolumn{4}{|c|}{14 soil layers } \\
\hline Snow layers & 3 & 3 & \multicolumn{4}{|c|}{12 snow layers } \\
\hline Photosynthesis & No & No & \multicolumn{4}{|c|}{ A-gs module } \\
\hline Vegetation types & 1 & 1 & \multicolumn{4}{|c|}{12} \\
\hline \multicolumn{7}{|l|}{ Hydrology } \\
\hline Sub-grid runoff & $b=0.5$ & $b=0.5$ & \multicolumn{4}{|c|}{$b=0.25$} \\
\hline Sub-grid drainage & Calibrated & Forced to 0. & \multicolumn{4}{|c|}{ No } \\
\hline \multicolumn{7}{|l|}{ Databases } \\
\hline Vegetation & ECOCLIMAP1 & ECOCLIMAP1 & \multicolumn{4}{|c|}{ ECOCLIMAP2 } \\
\hline Soil & INRA & INRA & \multicolumn{4}{|c|}{ HWSD } \\
\hline Topography & GTOPO30 & GTOPO30 & \multicolumn{4}{|c|}{ SRTM90 } \\
\hline \multicolumn{7}{|l|}{ Infrared radiation } \\
\hline Correction & Off & Off & Off & On & On & On \\
\hline \multicolumn{7}{|l|}{ Mountain specificity } \\
\hline Sub-grid topography & Off & Off & Off & Off & On & On \\
\hline Drainage reservoir & Off & Off & Off & Off & Off & On \\
\hline
\end{tabular}

ECMWF operational analysis thereafter. In France, the density of the observation network is very high because a network dedicated to climatology completes the less-dense synoptic network. There are therefore practically no regions with poor coverage, especially for precipitation, which is essential for hydrology, and the coarse resolution of the analysis first guess is not an issue. The analysed variables are then interpolated every hour on the SIM grid at a resolution of $8 \mathrm{~km}$, and this complete set of near-surface variables is then used to conduct offline simulations. The averages of the fields analysed or reconstructed by SAFRAN over the entire period over France, used as input data for offline experiments, are shown in Fig. 3, while the annual averages of these quantities are shown in Fig. 4.

\subsection{Datasets and validation tools}

Various datasets were used to evaluate the performance of the SIM model throughout the validation process to ensure that an improvement in the input climate data or physics simultaneously improved the surface or ground variables and river flows.

The Land Surface Analysis Satellite Applications Facility (LSAF) disseminates products based on data from the Meteosat second-generation geostationary satellites, in particular downwelling infrared radiation (LSA SAF; Trigo et al., 2011; http://lsa-saf.eumetsat.int, last access: September 2018). LSAF data covering the period from 1 August 2010 to 31 July 2015 are used here to assess the quality of SAFRAN's infrared radiation.
In addition to the infrared radiation data from Carpentras and Col de Porte already mentioned in Sect. 2.4, in situ data from the French GLACIOCLIM observation service (https://glacioclim.osug.fr, last access: January 2018) stations at Saint-Sorlin $(2620 \mathrm{~m})$ and Argentière $(1900 \mathrm{~m})$ were also used to assess SAFRAN's infrared radiation at altitude. The period covered runs from December 2005 to December 2015.

River flow observations are taken from the French national database Banque Hydro (http://hydro.eaufrance.fr/, last access: October 2019) from 1958 to 2018. Daily and monthly flow data from 470 selected gauging stations were used to evaluate river flows simulated by the MODCOU hydrogeological model. Only gauging stations with observations for at least half of the days over the total period were kept. The Nash-Sutcliffe efficiency (NSE; Nash and Sutcliffe, 1970) was used to evaluate the performance of the model, and the flow ratio between SIM simulations and observations was calculated to assess the bias of the system. The complementary cumulative distribution function (CCDF, below) of the NSE, which calculates the probability that the NSE is greater than a threshold averaged over the number of gauging stations in France, is also used as a measure to evaluate the NSE.

Observed snow depth is another independent dataset (i.e. not assimilated in the reanalysis process) used to evaluate the system. Measurements from 185 stations in the Alps, the Pyrenees, and Corsica at altitudes between 600 and $3000 \mathrm{~m}$ above sea level are used. They include 26 ultrasonic sensors (located mainly in high-altitude areas: the Nivose net- 

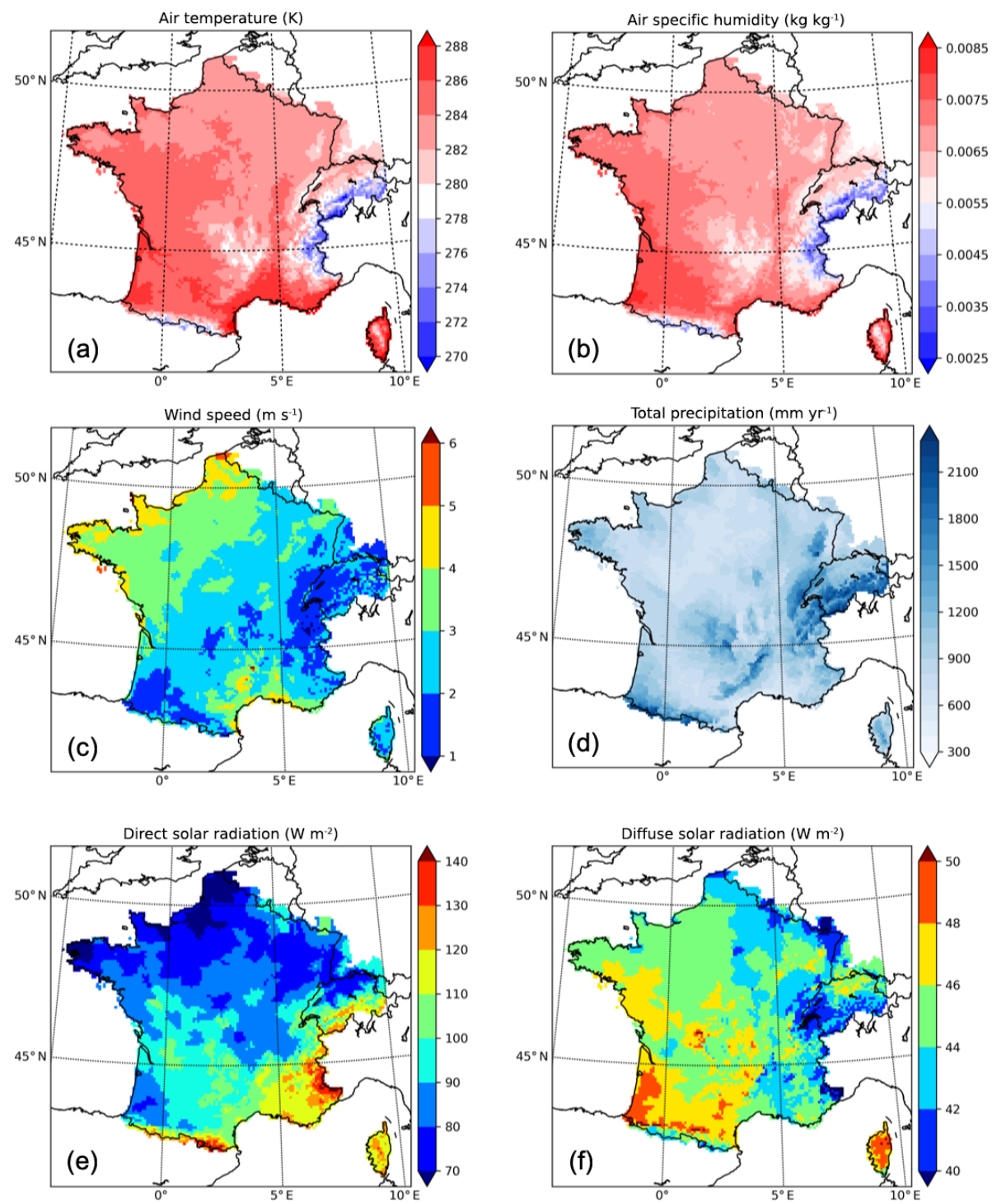

Figure 3. Maps of the annual average of the SAFRAN analysis for the period 1958-2018 of (a) air temperature at $2 \mathrm{~m}$, (b) specific air humidity at $2 \mathrm{~m}$, (c) wind speed at $10 \mathrm{~m}$, (d) total annual precipitation, (e) direct solar radiation, and (f) diffuse solar radiation.

work) and 161 stations operated by Météo-France partners, mainly at ski resorts, which are manual measurements using snow sticks. The daily total snow depth is used to calculate the bias and root mean square errors for the SIM_REF and SIM_NEW simulations over the period 1984-2016 between October and June. Note that most stations do not provide complete data for the entire period. The length of the measurement series and the number of seasons that stations are open are sources of variability in the scores. However, since very few series are complete, the choice was made to evaluate the performance of the model by considering as many stations as possible rather than trying to homogenize the length of the series.

The SAFRAN analysis is performed on homogeneous zones in terms of horizontal gradients, and the analysed fields are spatially interpolated to a regular $8 \mathrm{~km}$ grid taking altitude into account. Thus, the comparison of infrared radiation (IR) is made between the SAFRAN analysis interpolated at $8 \mathrm{~km}$ and the local observation. The horizontal variability of IR radiation at $8 \mathrm{~km}$ is small enough to allow a direct comparison with in situ observations. Moreover, the ISBA model outputs of ground temperature and snow depth profiles are relatively sparse, and only a direct comparison between the model outputs and the observations is possible. Finally, with respect to river flows, the MODCOU model grid varies in the range of 8 to $1 \mathrm{~km}$ near the riverbed, and the comparison between the model output and the observed flow is made by considering the flow at the river outlet and the corresponding model grid point in the $1 \mathrm{~km}$ hydrological network grid. This way of locally validating models by comparing the ob- 

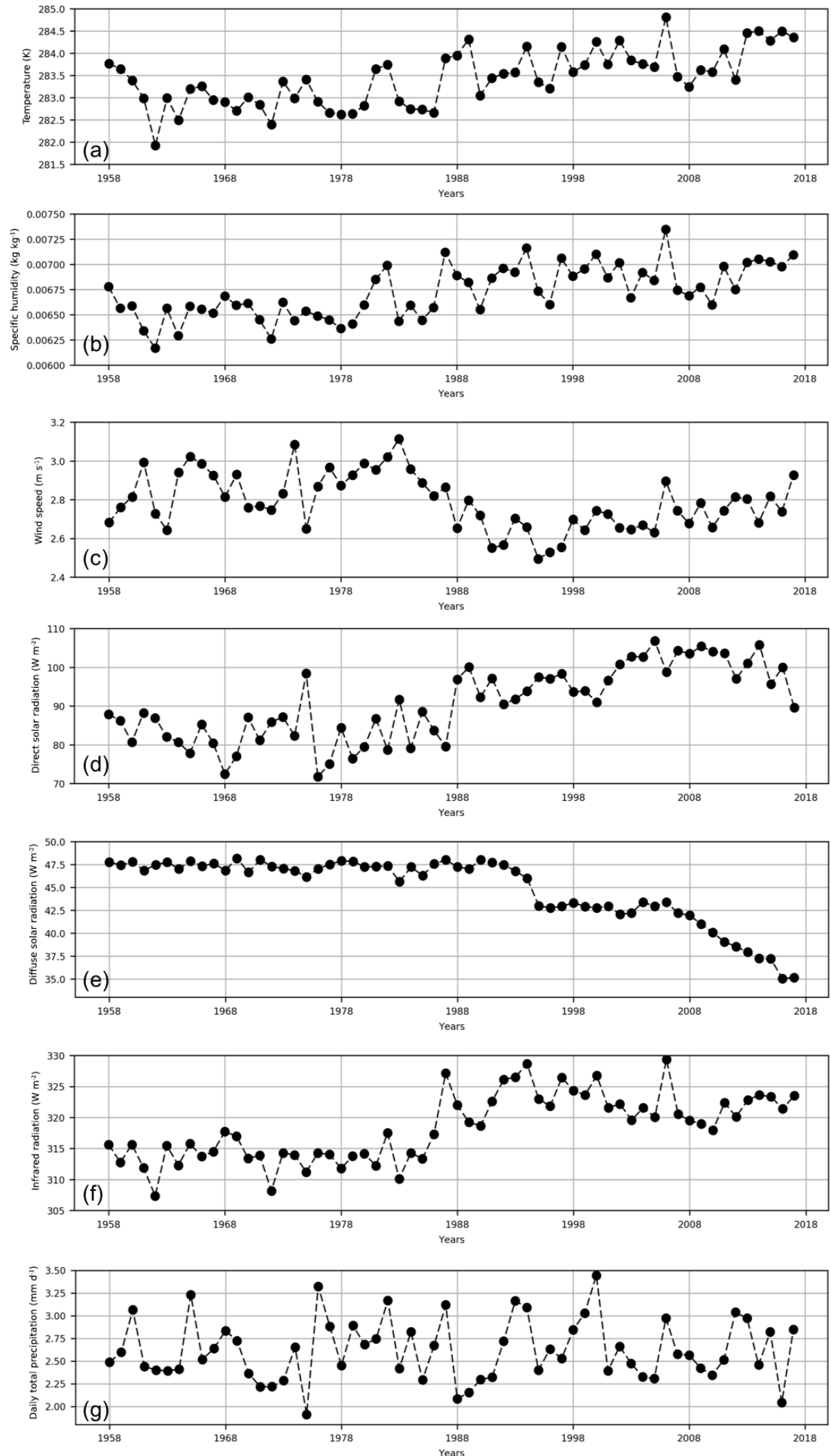

Figure 4. Annual average of the SAFRAN analysis of (a) air temperature at $2 \mathrm{~m}$, (b) specific air humidity at $2 \mathrm{~m}$, (c) wind speed at $10 \mathrm{~m}$, (d) direct solar radiation, (e) diffuse solar radiation, (f) infrared radiation, and (g) total precipitation rate. 
servation to the corresponding model grid point is not new and has been used in many studies in France and elsewhere (Habets et al., 2008; Decharme et al., 2013; Lafaysse et al., 2011; Vergnes et al., 2014).

\section{Results}

\subsection{Description of climate data}

Figure 4 shows the annual averages of atmospheric forcing from 1958 to 2018. The $2 \mathrm{~m}$ air temperature (Fig. 4a) and specific humidity (Fig. 4b) show natural interannual variability and a tendency to increase over time by about $1.4 \mathrm{~K}$ and $0.6 \mathrm{~g} \mathrm{~kg}^{-1}$ (linear regression of the time series of annual means), respectively. The abrupt change in temperature in 1987-1988, referred to by Brulebois et al. (2015), is not so obvious to explain. The $10 \mathrm{~m}$ wind speed (Fig. 4c) at the beginning and end of the analysis period is of the same order, with an amplitude of $2.8 \mathrm{~m} \mathrm{~s}^{-1}$ but with a significant decrease of $0.5 \mathrm{~m} \mathrm{~s}^{-1}$ between 1983 and 1995 , followed by a steady increase until 2018. The interannual variability is greater for precipitation than for the other variables, but shows no trend on average. Incident radiation also shows a remarkable change around 1988 with about $+15 \mathrm{~W} \mathrm{~m}^{-2}$ for direct solar radiation and $+5 \mathrm{~W} \mathrm{~m}^{-2}$ for infrared radiation between the periods before and after 1988. At the same time, diffuse solar radiation decreases by $10 \mathrm{~W} \mathrm{~m}^{-2}$ from 1988 onwards. On average, the total amount of solar and infrared energy received by the surface increases by about $10 \mathrm{~W} \mathrm{~m}^{-2}$. This behaviour is consistent with the discussion of Brulebois et al. (2015) and the analysis of Boé (2016) and may be caused by several factors. It can be argued that a decrease in aerosols and the increase in greenhouse gases in the atmosphere have significantly increased incident radiation as shown by climate studies (Wild, 2012). In addition to this physical reason, more technical reasons such as changes over time in the density of assimilated observations or changes in the ECMWF operational system may have affected the ERA40 reanalysis. Although the model used in the reanalysis is a frozen version, the reanalysis system includes input observations whose density varies significantly over time (Uppala et al., 2005). In addition, during the production of the ERA-40 reanalysis, the ECMWF operational data assimilation system has evolved considerably and switched to a 4D-Var variational method (1997) compared to the 3D-Var method previously used. As a consequence, the calculation of the error covariances of the observations and the guess were revised in the 4D-Var, but also the 3D-Var, and directly impacted the ERA-40 reanalysis. The comparison in terms of bias and root mean square error (RMSE) at the four weather stations measuring infrared radiation is summarized in Table 2. With the exception of the Carpentras station, where the LSAF IR radiation is almost unbiased and the error is the smallest compared to SAFRAN, the scores are better for the high-altitude stations with SAFRAN when the correction is applied. Due to their high altitude, no correction was applied at Argentière or Saint-Sorlin. At the Argentière station, the bias and root mean square error are lower with SAFRAN than with LSAF. At Saint-Sorlin, the bias is higher with SAFRAN but the RMSE is of the same order of magnitude as LSAF.

\subsection{Impact of new model configurations}

The first comparison concerns the SIM_REF2 experiment in which river flow is slightly underestimated compared to SIM_REF (not shown), and the underestimation is corrected by calibrating the sub-grid drainage term. In the SIM_REF simulation, the ratio of simulated to observed flow is centred around 1, and the daily efficiency range (NSE below) characterized by its CCDF is larger for all stations. SIM_PHY does not consider any parameterization of the sub-grid drainage and is therefore closer to the SIM_REF2 simulation in terms of sub-grid hydrology. Figure 5 shows the comparison of each SIM simulation with the observed river flow for the 470 gauging stations. SIM_PHY tends to overestimate flows, as indicated by the average ratio between simulated and observed flows. SIM_PHY shows slightly poorer results for NSE, ranging from 0.5 to 0 (about $40 \%$ of the stations), but in this case both models do not perform very well. Most of the stations affected by deterioration in the lower part of the NSE CCDF have an NSE below 0.55 and represent about $57 \%$ of the total number of stations. Part of the explanation comes from the calibration of the sub-grid drainage in SIM_REF, which is not done in SIM_PHY. However, the NSE CCDF shows that SIM_PHY outperforms SIM_REF (and also SIM_REF2, not shown) for NSEs greater than 0.56 , which corresponds to half the total number of stations and highlights the added value of physics associated with a better description of vegetation types and the use of other more accurate databases. Figure 5 shows how the scores are improved for experiments with corrected infrared radiation (SIM_FRC), sub-grid orography (SIM_TOP), and hydrology (SIM_NEW) in terms of both the NSE CCDF and flow ratio. The bias in river flow is significantly reduced when infrared radiation is increased due to higher total evaporation, resulting in less water available in rivers. However, a positive bias remains, which is expected, since SIM simulates natural runoff and river flow, i.e. without abstraction or diversion, while some basins are influenced by human activity. In some basins, the human footprint on the landscape is characterized by an increase in urban and agricultural areas and the presence of dams. In the model, urban areas have been replaced by rocks, a type of natural surface, to represent the presence of urban areas that enhance surface runoff. However, the model does not explicitly represent irrigation or the impact of the presence of dams on river flow. The basins impacted by human activity are of great interest for the evaluation as they allow for quantifying errors in the system and proposing improvements. The SIM_FRC and SIM_TOP NSE scores are 
Table 2. Annual mean bias and RMSE of LSAF, SAFRAN, and corrected SAFRAN infrared radiations at Carpentras (95 m), Col de Porte (1340 m), Argentière (1900 m), and Saint-Sorlin (2620 m).

\begin{tabular}{|c|c|c|c|c|c|c|}
\hline & \multicolumn{2}{|c|}{$\begin{array}{l}\text { LSAF IR radiation } \\
\qquad \mathrm{W} \mathrm{m}^{-2}\end{array}$} & \multicolumn{2}{|c|}{$\begin{array}{c}\text { SAFRAN IR radiation } \\
\text { without correction } \mathrm{W} \mathrm{m}^{-2}\end{array}$} & \multicolumn{2}{|c|}{$\begin{array}{l}\text { SAFRAN IR radiation } \\
\text { with correction } \mathrm{W} \mathrm{m}^{-2}\end{array}$} \\
\hline & Bias & RMSE & Bias & RMSE & Bias & RMSE \\
\hline Carpentras & 1.3 & 10.2 & -8.4 & 21.5 & 3.1 & 20.3 \\
\hline Col de Porte & -10.3 & 20.2 & -14.4 & 20.4 & -9.3 & 17.5 \\
\hline Argentière & -18.8 & 32.6 & -3.6 & 18.5 & -3.6 & 18.5 \\
\hline Saint-Sorlin & 0.1 & 27.8 & 10.5 & 25.3 & 10.5 & 25.3 \\
\hline
\end{tabular}

very close and better than SIM_PHY for all stations and SIM_REF for about $75 \%$ of the stations with NSE greater than 0.4. Finally, SIM_NEW and SIM_TOP tend to overestimate river flow, but their NSEs are significantly better than SIM_REF for all NSE ranges.

Figure 6 presents a map of the differences in mean annual NSEs (for stations with positive NSEs) between the different configurations. Over the entire reanalysis period, in Fig. 6a, it is first confirmed that SIM_PHY alone does not improve the flow simulations everywhere in France but only for the gauging stations that were already reasonably represented (with NSEs above 0.56). Second, the new IR forcing improves the scores almost everywhere except in two isolated stations in the Seine basin (Fig. 6b). As expected, SIM_TOP only has an impact on mountains, especially over the Alps (Fig. 6c). Finally, the comparison between SIM_NEW and SIM_TOP highlights the advantages of using an underground mountain reservoir for snow (Fig. 6d). It should be noted that the number of stations is reduced in Fig. $6 c$ and d because these experiments do not encompass the entire territory. In Fig. 7, SIM_NEW is compared with SIM_REF so that it reveals the advantages of all the changes. The SIM_NEW NSE map indicates that the model explains a large part of the flow variance at most stations (brown to green colours), but some stations still have average (red) to low (blue) NSE values. In particular, the gauging stations in northern France are not well simulated, in addition to the Alpine region, which is known to have significant anthropogenic influences on the flow regime.

\subsection{Seasonal river flows}

To complement the previous results and to demonstrate the successive improvements in simulated flows, seasonal scores were displayed over the 60-year simulation period using Taylor plots, which have been recognized to be a useful tool for graphically summarizing how a set of simulations compares to observations (Taylor, 2001). A set of experiments can be analysed in terms of correlation, centred root mean square difference (RMSD), and the magnitude of their variation represented by the normalized standard deviation. These scores are calculated from all daily observations and simulations.
Seasonal Taylor plots (DJF, MAM, JJA, and SON for winter, spring, summer, and fall, respectively) of the different experiments are presented in Fig. 8. As a result, regardless of the season, the SIM_NEW simulation has the highest correlation and the lowest RMSD, except perhaps for JJA, the season with the highest normalized standard deviation. For DJF, the scores are very good with relatively little spread, while for JJA, the scores are still tightly clustered but the RMSD is higher. MAM and SON confirm the interest of using an underground reservoir to conserve water in the mountains before releasing it in the spring.

\subsection{Extreme river flows}

The previous results showed how SIM_NEW behaved on average over the 60-year simulation period. In order to assess the ability of the new system to correctly simulate extreme river flows and thus to distinguish between high and low flow periods, the deciles of daily river flows were calculated, and special attention was paid to decile $Q 10$ corresponding to low flow states and decile $Q 90$, the threshold above which a flow is considered to be decadal (here defined as a flood).

As shown in Fig. 9, $Q 10$ and $Q 90$ first indicate that in very dry periods (flows less than or equal to $Q 10$ ), all the simulations except SIM_NEW underestimate the amplitude of the variations. Furthermore, for the SIM_NEW experiment, the correlation, the RMSD, and the normalized standard deviation are the best. The variability in terms of normalized standard deviation is reversed when considering floods $(Q 90)$ versus dry periods $(Q 10)$. Again, SIM_NEW has the smallest RMSD value and all simulation correlations are greater than 0.99. Figure 10 compares the observed and simulated monthly flows of the Garonne River at Lamagistère with SIM_NEW and confirms the model's ability to simulate low flows during the summer seasons fairly accurately and its tendency to overestimate flood peaks. 

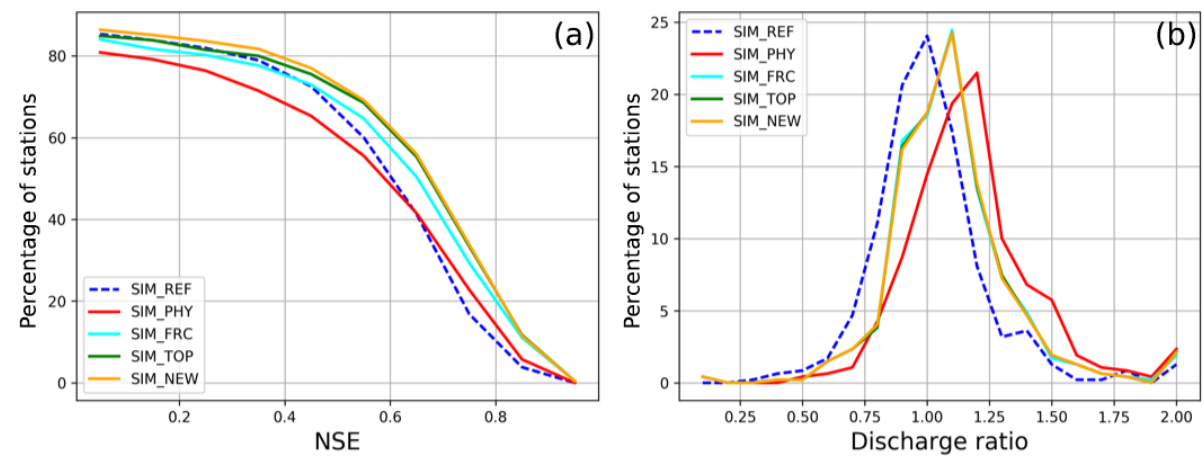

Figure 5. Comparison of the NSE CCDF (a) and the simulated to observed flow ratio (b) for SIM_REF (dashed blue line), SIM_PHY (solid red line), SIM_FRC (solid cyan line), SIM_TOP (solid green line), and SIM_NEW (solid orange line).
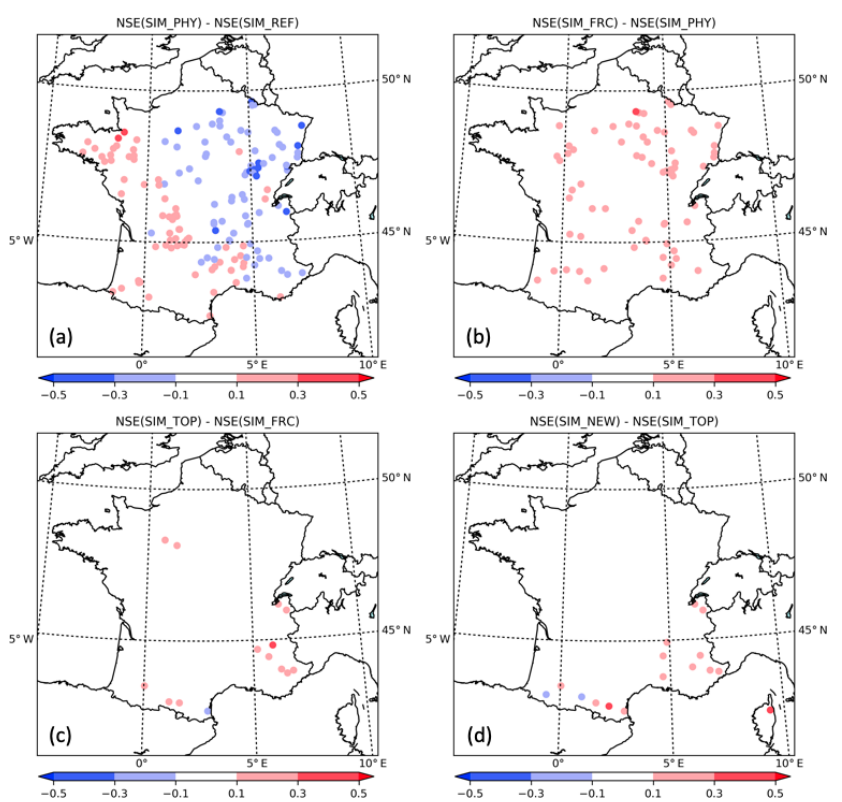

Figure 6. Maps of the difference in mean NSE for NSE $>0$ between the following simulations: (a) SIM_PHY and SIM_REF, (b) SIM_FRC and SIM-PHY, (c) SIM_TOP and SIM_FRC, (d) SIM_NEW and SIM_TOP.
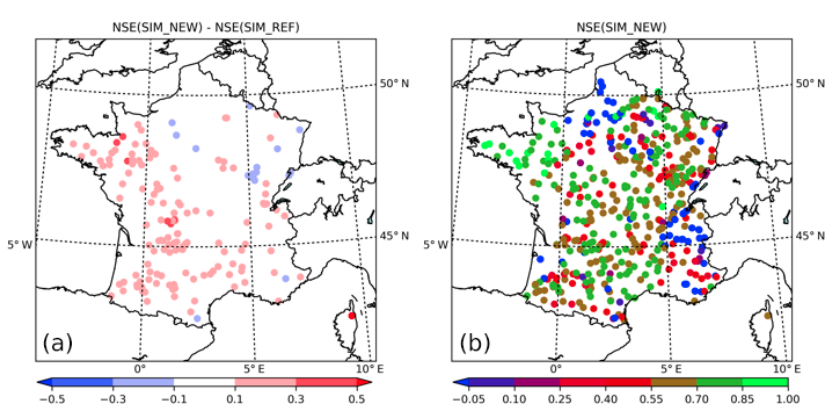

Figure 7. Map of the difference in mean NSE for NSE $>0$ between SIM_NEW and SIM_REF (a) and the SIM_NEW NSE map (b).
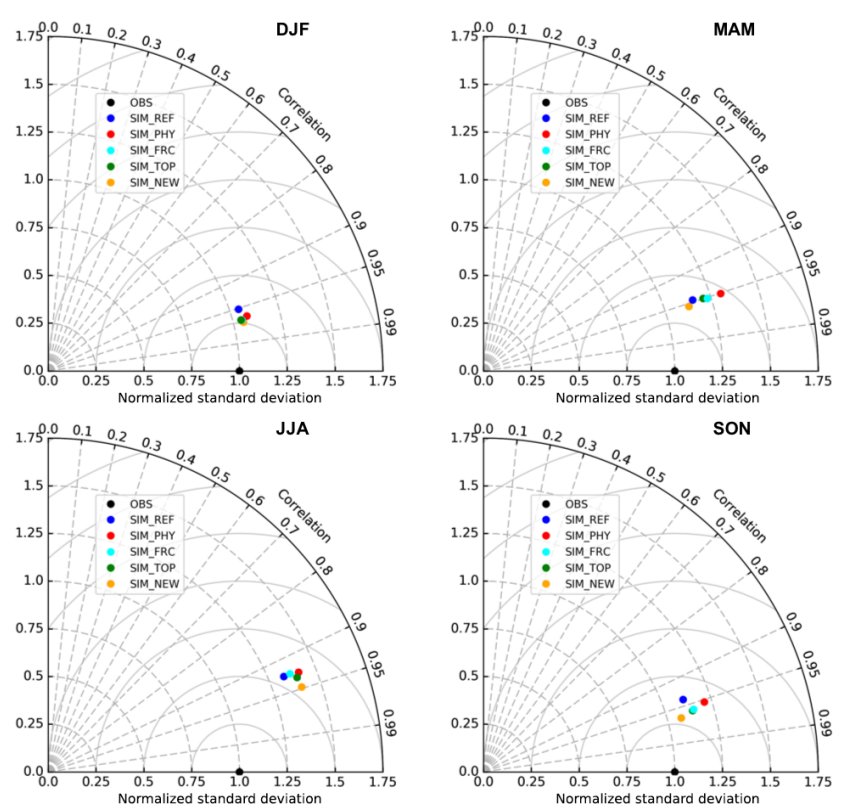

Figure 8. Taylor diagrams of seasonal river flows for the different experiments over the period 1958-2018.
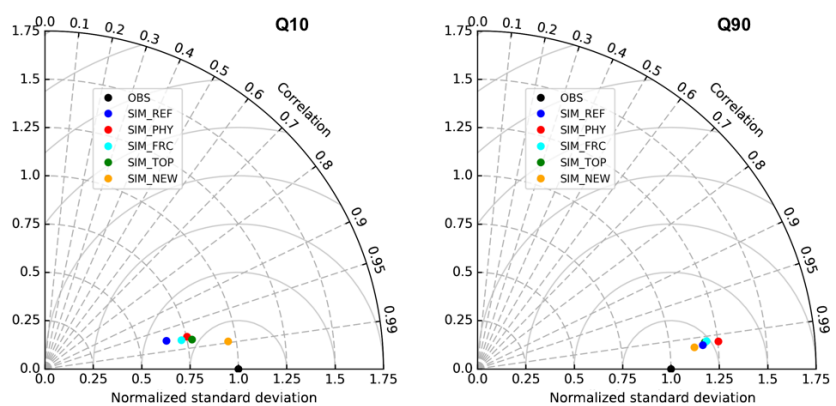

Figure 9. Taylor diagram of $Q 10$ and $Q 90$ deciles of river flows over the period 1958-2018. 


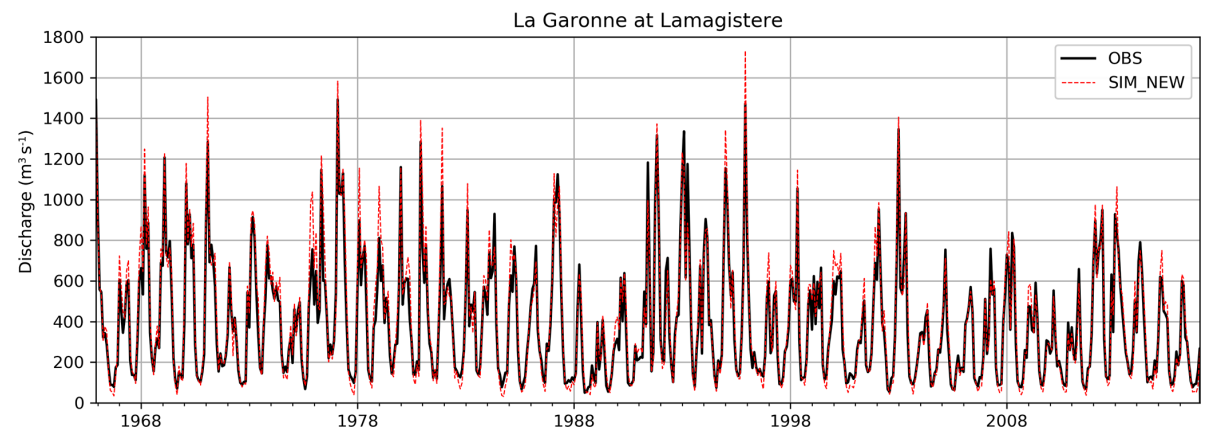

Figure 10. Comparison of monthly river flows with SIM_NEW for the Garonne at Lamagistère over the period 1958-2018.

\subsection{Snow height}

To complement the previous results with respect to flows, a comparison of the snow depths between SIM_REF and SIM_NEW was carried out using the 185 stations described in Sect. 3.2. In Fig. 11, the spatial variability of scores is presented as a function of elevation with notched box plots in which the boxes represent the interquartile range, the whiskers the 10th and 90th percentiles, and the notch the $90 \%$ confidence interval of the median estimated by a bootstrap sampling technique among the available stations. The SIM_REF simulation has a positive median bias at the lowest elevations and a negative median bias between 2000 and $2400 \mathrm{~m}$, while the SIM_NEW simulation is unbiased at any elevation. The variability of the bias between stations is also reduced in the SIM_NEW simulation. Consistently, a significant reduction in MSE is obtained at the lowest and highest altitudes with SIM_NEW, as is a reduction in the 90th percentile MSE at all altitudes. These results are consistent with improved altitudinal discretization in mountainous areas, which reduces the altitude differences between the simulated grid cells and the observation stations. Slight improvements in SIM_NEW scores could have been obtained by linearly interpolating the simulated snow depths at the two layers surrounding the observation. However, the point vertically closest to the observation was chosen in order to use the same selection as in SIM_REF. It should also be noted that improvements in the snow parameterization, but also the use of more accurate vegetation maps, can explain some of the improvement in scores (Decharme et al., 2016).

\subsection{Changes in the simulated water and energy budgets}

This section compares the climatology of the SIM system before and after the changes made. The aim is to qualitatively identify the impact of the new model on the distribution of energy fluxes, which is important for certain hydrological or agriculture-related applications. Maps of the Bowen ratio and the evaporation to precipitation ratio are shown in Fig. 12. The areas with the highest Bowen ratio are located in the mountains where snowfall limits evapora- tion, along the Mediterranean coast where annual precipitation is lower in quantity and incident radiation rather strong, and in a large area covering the Garonne basin and part of the Loire and Seine basins, characterized by high vegetation fractions. The evaporation to precipitation ratio is also highest in the lowland areas where the Bowen ratio is high. On the mountains, heavy precipitation and limited evaporation due to snow lead to the lowest evaporation to precipitation ratio. These results are comparable to those obtained by Habets et al. (2008) for another period, except that in SIM_NEW, the Landes forest (south-western France on the Atlantic coast) has a higher Bowen ratio. The first reason comes from the difference in the parameterization of photosynthesis, more precisely the parameterization of leaf conductance used in SIM_REF based on Jarvis (1976) and SIM_NEW based on ISBA-A-gs (Calvet et al., 1998), which explicitly models photosynthesis (thus the canopy resistance is more physically based) and models plant stress in a more detailed manner; this considerably reduces evaporation over vegetated areas. Thus, the surface energy budget tends to increase the sensible heat flux. The second reason is related to the increase in incoming infrared radiation; this increases the sensible heat flux and decreases the latent heat flux, which generally occurs on dry soils with low evaporation capacity. The interannual variability of the evaporation to precipitation $(E / P$ hereafter) ratio and the Bowen ratio are presented in Fig. 13 for SIM_REF, SIM_PHY, and SIM_NEW to first characterize the old system relative to the new one and to highlight the impact of changes from SIM_PHY to SIM_NEW on the energy budget. $E / P$ is greater in SIM_REF than in the other two simulations each year, and $E / P$ in SIM_NEW is closer to SIM_REF than in SIM_PHY. Total precipitation is very similar but slightly lower in SIM_REF and in SIM_PHY or SIM_NEW due to the representation of subgrid orography in the mountains, enhanced by a higher resolution of the orography, which allows for finer vertical discretization. Therefore, higher $E / P$ corresponds to higher total evaporation. In SIM_NEW, the ratio of simulated to observed flow is in excess, whereas it is better simulated in SIM_REF with a peak centred around 1. This result is consistent with an evaporation deficit in SIM_NEW compared 

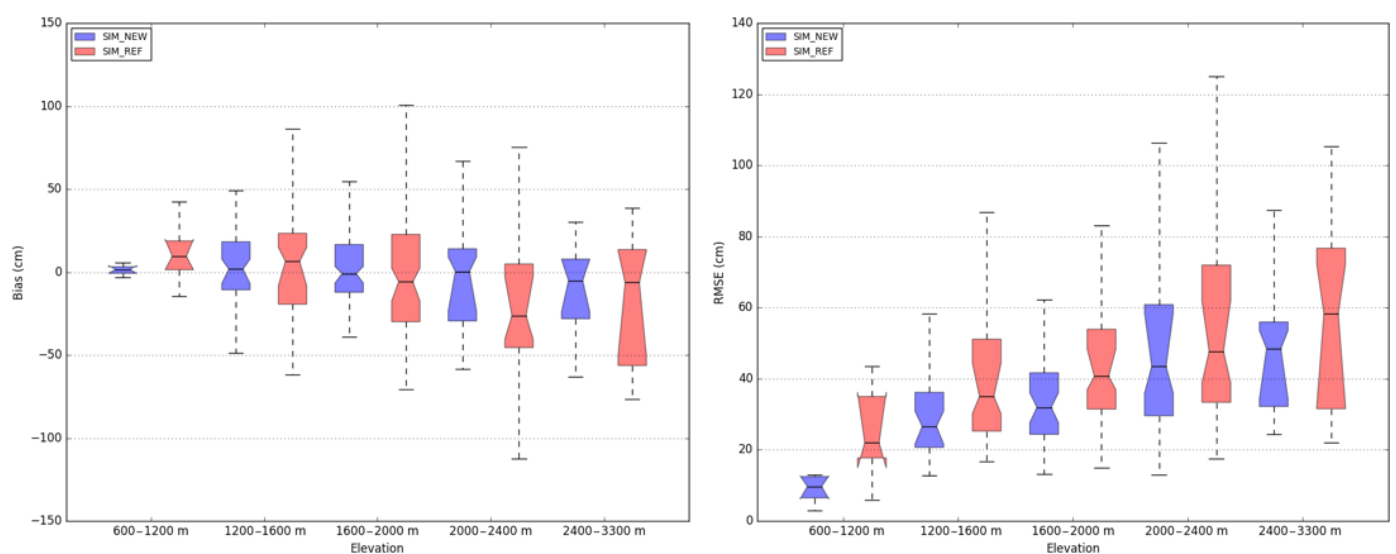

Figure 11. Bias and RMSE of daily total snow depth for SIM_NEW (blue) and SIM_REF (red) simulations as a function of elevation. The scores are computed for 185 stations over the period 1984-2016 for months between October and June. The boxes represent the interquartile interval, the whiskers the 10th and 90th percentiles, and the notch the $90 \%$ confidence interval of the median estimated by a bootstrap sampling technique among the available stations.

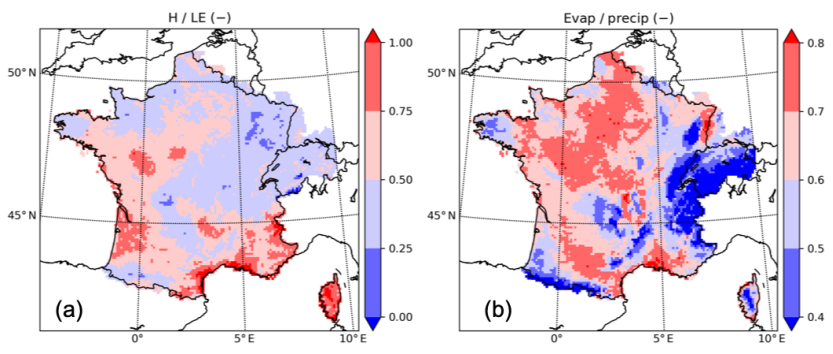

Figure 12. Maps of the mean annual Bowen ratio (a) and evaporation to precipitation ratio (b) for SIM_NEW on average over the period 1958-2018.

to SIM_REF. The Bowen ratio is lowest for SIM_REF, increases in SIM_PHY, and is highest in SIM_NEW, which already tends to evaporate more than SIM_PHY. This result shows that the sensible heat flux in SIM_NEW is much higher than in SIM_PHY, mainly due to the increased incoming infrared radiation, which partially compensates for the evaporation deficit.

\section{Discussion}

\subsection{Climatic data}

As shown in Fig. 4, there is heterogeneity in the forcing data, particularly with respect to radiation. There are two possible reasons for the break in the time series; the first is due to the large-scale analysis used to reconstruct temperature, humidity, and cloudiness profiles. As explained in Sect. 4.1, the calculations of these profiles have varied over time as a result of improvements in the global data assimilation systems used in the ERA-40 reanalysis production. The second reason is the variation in the observation density network over time. Indeed, from 1958 to the present, substantial changes have been observed in the deployment of new weather stations. The combination of these two changes means that the SAFRAN reanalysis is not homogeneous over time, and it seems important to understand how the optimal interpolation results are influenced by these changes when analysing the simulation results. However, an abrupt change may also be due to the darkening-lightening effect (Wild, 2012; Brulebois et al., 2015; Boé, 2016).

As already mentioned, the uncertainty in SAFRAN's IR radiation is significant. The ability to observe the IR in the plains and mountains allowed for a fair comparison between LSAF and SAFRAN products without correction (SIM_PHY) and with correction (SIM_FRC). The impact of this variable is very important, especially over snow (Quéno et al., 2020; Sauter and Obleitner, 2015); therefore, an extension of the in situ observation network would allow for a better understanding of its spatial variability and the potential improvement of model simulations. The extension of the correction to the entire French territory is debatable, but this decision was guided by the positive bias of river flows and also by the desire to have a more realistic energy input in mid-mountain areas (i.e. below $1500 \mathrm{~m}$ ) in order to better model the evolution of the snowpack.

We also compared the simulated soil temperatures to the observations made over France. The IR correction on soil temperature has a positive impact and significantly reduces biases and RMSEs (not shown). The results are consistent with and of the same order of magnitude as those obtained by Decharme et al. (2013).

\subsection{River flows}

The results show that SIM_REF simulates the correct ratio between modelled and observed river flow (centred around 


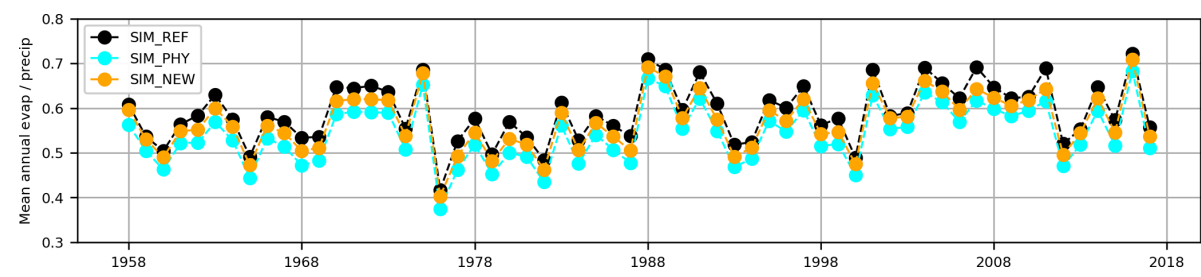

Figure 13. Mean annual evaporation to precipitation ratio (a) and Bowen ratio (b) for experiments SIM_REF, SIM_PHY, and SIM_NEW.

1), whereas in SIM_PHY, this ratio indicates an overestimation. However, good results in SIM_REF are due to error compensation since despite a radiative deficit, river flow is rather well simulated. In SIM_PHY, as explained in the model description, more complexity has been added to the model based on a better representation of physics. The calculations, performed on each of the vegetation types, use the A-gs photosynthesis parameterization, which tends to produce less evaporation on the vegetation, leading to more water available in the rivers. On the other hand, it has already been mentioned that radiative forcing is underestimated. The combination of more water available in the soil and less radiative energy to evaporate leads to an overestimation of river flows. By correcting for IR radiation, the SIM_FRC simulation shows a clear improvement in river flow scores, with a peak of the modelled to observed ratio closer to 1 and an improved daily efficiency range in almost all cases, except perhaps for NSEs below 0.4, but in this case the difference with SIM_REF is very small. The implementation of the sub-grid topography with the use of elevation bands (SIM_TOP) and the sub-grid hydrology with the inclusion of a snow reservoir (SIM_NEW) essentially impact the hydrology in the mountains and thus the snow and river flows that are affected by snowmelt.

\subsection{Snow depth}

The snow depth simulation is of equivalent quality on the 9892 meshes in SIM_FRC, SIM_TOP, and SIM_NEW because the same IR correction is applied. On the other hand, the sub-grid representation of the topography improves the realism of SIM_TOP and SIM_NEW in terms of snow depth but applies only to the 1044 additional grid cells. However, for the evaluation of the snow depth, the comparison can only be made on the 9892 cells that correspond to the SIM_REF grid. In addition, in order not to disadvantage SIM_REF and to assess the impact of changes in physics and atmospheric fields, sub-grid processes in SIM_TOP and SIM_NEW were not considered in the evaluation (the additional vertical levels of the 1044 cells were not used). It was decided to present the fairest comparison with SIM_REF by only considering SIM_PHY. Under these conditions in which sub-grid effects are not activated, SIM_PHY is quite close to the other three simulations; the only difference is related to the change in IR forcing, limited below $1340 \mathrm{~m}$.

\subsection{Sub-grid hydrology}

This method showed that the hydrology of mountainous areas was improved because the analysed precipitation rate and phase were better represented for each altitude band than when averaged vertically, resulting, in the case of the $\mathrm{Du}$ rance River (Lafaysse et al., 2011), in a decrease in the overestimated spring peak flow associated with a better phase between the observed monthly flow and the simulated flow. However, summer and winter peak flows were still significantly underestimated by the model. During long periods of drought without precipitation or snowmelt, river flows are controlled by subsurface drainage. In the framework of the Aqui-FR project (http://www.geosciences.ens.fr/aqui-fr/, last access: December 2019) aimed at developing a platform with multiple regionally specialized hydrogeological models over France to simulate flows and water table heights, aquifers are explicitly simulated, and the water flows of SURFEX (Masson et al., 2013) used as inputs should not be impacted by an empirical representation of aquifers. Moreover, in Aqui-FR, some hydrogeological applications have been calibrated using SURFEX runoff and infiltration water flows as inputs (Vergnes et al., 2020).

\section{Conclusions and outlook}

This study illustrates how developments over the last 10 years are improving the SIM hydrometeorological system. Several important changes have been made, particularly in the soil physics of the ISBA model wherein the force-restore method has been abandoned and replaced by the multi-layer soil diffusion method. At the same time, as described in Sect. 2, the snow model has been revised to improve vertical layering, snow compaction, and solar energy transmission within the snowpack through the use of spectral albedo, as is done in more advanced models. The model was run according to the vegetation tiling approach, with each of the 12 vegetation types characterized by its own set of parameters, in contrast to the single vegetation type approach whereby the parameters are aggregated. Then, more accurate databases for soil, orography, and land use were used. A more precise infrared forcing significantly improved the results, as did the use of a groundwater reservoir in mountains associated with a specific vertical discretization of the 
massifs. The new configuration of the model, including all the new or updated functionalities mentioned above, proved to be more efficient than the old system and was therefore better adapted to water resource studies. Comparisons with independent observations of daily total snow depth and river flows were made and confirmed that the scores were improved. In addition, the new SIM system better represented river flow extremes for both low and high flow periods.

Some perspectives can be proposed to improve the SIM system. The first is to improve the description of climate. It was found that SAFRAN worked well in most cases, but some shortcomings remained. A new near-surface reanalysis system is being developed at Météo-France to replace SAFRAN. It includes a new surface analysis of air temperature, relative humidity at $2 \mathrm{~m}$, and daily precipitation, and it uses high-resolution model outputs as a first guess of the analysis. In addition, as part of the Copernicus programme, a $5.5 \mathrm{~km}$ high-resolution reanalysis will be produced over Europe and will be an interesting product to compare with SAFRAN over France.

The second is to improve the representation of surfaces in the model. Indeed, the ecosystem database is representative of the 1999-2006 period. For more recent simulations or quasi-real-time applications, it would be interesting to study the contribution of new high-resolution satellite products, such as the land cover product of the European Space Agency and the Climate Change Initiative, or certain other parameters derived from Copernicus products, such as albedo, which allow for a better description of surface types.
The third concerns improving the physics of the model, more specifically the use of the multi-energy balance (MEB) scheme (Boone et al., 2017; Napoly et al., 2017) to enable the explicit calculation of the interactions of the canopy with the air and the ground. The MEB model showed some modest gains within the SIM_REF simulation owing to a better temporal partitioning between bare soil evaporation and transpiration (Napoly, 2016). Moreover, the MEB model demonstrated that the use of litter in forests improved surface flux results.

Considering anthropization, in particular irrigation and the presence of dams, could benefit the SIM system in improving its realism and allowing for more accurate comparisons with gauging stations in anthropized basins. Irrigation is currently being developed in the ISBA model, and the integration of dams is a longer-term project. Finally, a better representation of groundwater and its characteristics in France is another challenge to be taken up. 


\section{Appendix A: The formula of the infrared correction}

This correction was proposed to compensate for a deficit in longwave radiation analysed by SAFRAN compared with infrared measurements from two reference meteorological stations, Carpentras and Col de Porte, respectively located in south-eastern France and the Alps. The correction is applied below $1340 \mathrm{~m}$. The comparison was made for measurements collected between August 1993 and August 1994 every 3 h.

The correction is written as follows:

$\varepsilon(\sigma)=\left(-5.42+1.14 \sigma-0.11 \sigma^{2}\right) \times 10^{-2}$,

$\mathrm{LWD}_{\text {cor }}=\mathrm{LWD}_{\mathrm{ref}} /[1+\varepsilon(\sigma)]$,

where $\sigma$ is the cloudiness analysed in octas, $L W D_{\text {ref }}$ the SAFRAN longwave downward radiation, and $\mathrm{LWD}_{\text {cor }}$ the longwave downward radiation when the correction is applied, i.e. when it is divided by $1+\varepsilon(\sigma)$. Figure A1 shows the magnitude of the correction as a function of cloudiness. The increase in radiation is highest under clear-sky conditions, decreases with cloudiness up to 5 octas, and increases again for cloudier skies.

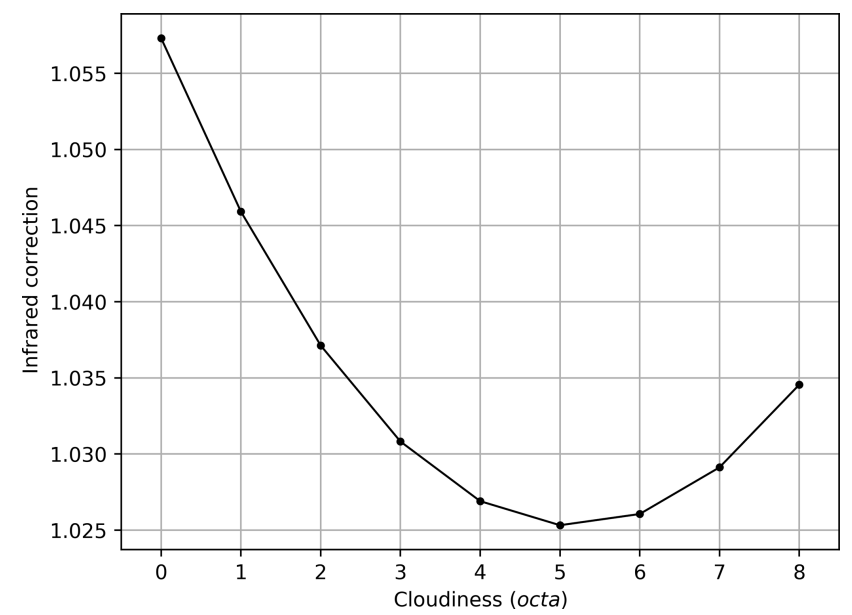

Figure A1. Infrared correction as a function of cloudiness. 
Code availability. The SURFEX v8.0 source code, including the ISBA code, used in this study is available at https://doi.org/10.5281/zenodo.3685899 (Le Moigne, 2020), as is the SAFRAN code. The post-processing codes, including the scores package from the open-source snowtools project, are also available there.

Data availability. The results of all the models examined here and the $\mathrm{R}$ and Python programmes for plotting the results are available at https://doi.org/10.5281/zenodo.3685899 (Le Moigne, 2020).

Author contributions. Model developments were performed by PLM and EM for the SAFRAN analysis on France, SF for SURFEX, BD and AB for the diffusive version of SURFEX-ISBA, and FH for MODCOU. PLM and FB designed the experiments and carried them out. ML carried out the comparison of the results on snow. DL provided valuable Python scripts for the figures. JB and ML first tested the model for their own research. PE, FB, and FRR are responsible for the SIM operational suite at Météo-France. PLM prepared the paper with the help of all co-authors.

Competing interests. The authors declare that they have no conflict of interest.

Review statement. This paper was edited by Sophie Valcke and reviewed by two anonymous referees.

\section{References}

Albergel, C., de Rosnay, P., Gruhier, C., MunPoz-Sabater, J., Hasenauer, S., Isaksen, L., Kerr, Y., and Wagner, W.: Evaluation of remotely sensed and modelled soil moisture products using global ground-based in situ observations, Remote Sens. Environ., 118, 215-226, 2012.

Albergel, C., Munier, S., Leroux, D. J., Dewaele, H., Fairbairn, D., Barbu, A. L., Gelati, E., Dorigo, W., Faroux, S., Meurey, C., Le Moigne, P., Decharme, B., Mahfouf, J.-F., and Calvet, J.-C.: Sequential assimilation of satellite-derived vegetation and soil moisture products using SURFEX_v8.0: LDAS-Monde assessment over the Euro-Mediterranean area, Geosci. Model Dev., 10, 3889-3912, https://doi.org/10.5194/gmd-10-3889-2017, 2017.

Alkama, R., Decharme, B., Douville, H., Becker, M., Cazenave, A., Sheffield, J., Voldoire, A., Tyteca, S., and Le Moigne, P.: Global evaluation of the ISBA-TRIP continental hydrological system. Part I: Comparison to GRACE terrestrial water storage estimates and in situ river discharges, J. Hydrometeorol., 11, 601-617, https://doi.org/10.1175/2010JHM1211.1, 2010.

Barthel, R. and Banzhaf, S.: Groundwater and surface water interaction at the regional-scale - a review with focus on regional integrated models, Water Resour. Manage., 30, 1-32, 2016.

Best, M., Abramowitz, G., Johnson, H., Pitman, A., Balsamo, G., Boone, A., Cuntz, M., Decharme, B., Dirmeyer, P., Dong, J., Ek, M., Guo, Z., Haverd, V., van den Hurk, B. J. J., Nearing, G. S.,
Pak, B., Peters-Lidard, C., Santanello Jr., J. A., Stevens, L., and Vuichard, N.: The plumbing of land surface models: benchmarking model performance, J. Hydrometeor., 16, 1425-1442, 2015.

Biancamaria S., Mballo, M., Le Moigne, P., Sánchez Pérez, J.M., Espitalier-Noël, G., Grusson, Y., Cakir, R., Häfliger, V., Barathieu, F., Trasmonte, M., Boone, A., Martin, E., and Sauvage, S.: Total water storage variability from GRACE mission and hydrological models for a $50,000 \mathrm{~km} 2$ temperate watershed: the Garonne River basin (France), J. Hydrol. Regional Studies, 24, 100609, https://doi.org/10.1016/j.ejrh.2019.100609, 2019.

Boé, J.: Modulation of the summer hydrological cycle evolution over western Europe by anthropogenic aerosols and soilatmosphere interactions, Geophys. Res. Lett., 43, 7678-7685, https://doi.org/10.1002/2016GL069394, 2016.

Boone, A. and Etchevers, P.: An Intercomparison of Three Snow Schemes of Varying Complexity Coupled to the Same Land Surface Model: Local-Scale Evaluation at an Alpine Site, J. Hydrometeorol., 2, 374-394, https://doi.org/10.1175/15257541(2001)002<0374:AIOTSS>2.0.CO;2, 2001.

Boone, A., Samuelsson, P., Gollvik, S., Napoly, A., Jarlan, L., Brun, E., and Decharme, B.: The interactions between soil-biosphereatmosphere land surface model with a multi-energy balance (ISBA-MEB) option in SURFEXv8 - Part 1: Model description, Geosci. Model Dev., 10, 843-872, https://doi.org/10.5194/gmd10-843-2017, 2017.

Boone, A., Calvet, J.-C., and Noilhan, J.: Inclusion of a Third Soil Layer in a Land Surface Scheme Using the Force-Restore Method, J. Appl. Meteorol., 38, 1611-1630, 1999.

Boone, A., Habets, F., Noilhan, J., Clark, D., Dirmeyer, P., Fox, S., Gusev, Y., Haddeland, I., Koster, R., Lohmann, D., Mahanama, S., Mitchell, K., Nasonova, O., Niu, G.-Y., Pitman, A., Polcher, J., Shmakin, A. B.,Tanaka, K., Van den Hurk, B., Vérant, S., Verseghy, D., Viterbo, P., and Yang, Z.-L.: The rhoneaggregation land surface scheme intercomparison project: An overview, J. Climate, 17, 187-208, 2004.

Boone, A., De Rosnay, P., Balsamo, G., Beljaars, A., Chopin, F., Decharme, B., Delire, C., Ducharne, A., Gascoin, S., Grippa, M., Guichard, F., Gusev, Y., Harris, P., Jarlan, L., Kergoat, L., Mougin, E., Nasonova, O., Norgaard, A., Orgeval, T., Ottlé, C., Poccard-Leclercq, I., Polcher, J., Sandholt, I., Saux-Picart, S., Taylor, C., and Xue, Y.: The amma land surface model intercomparison project (almip), B. Am. Meteorol. Soc., 90, 1865-1880, https://doi.org/10.1175/2009BAMS2786.1, 2009.

Boone A., Best, M., Cuxart, J., Polcher, J., Quintana, P., Bellvert, J., Brooke, J., Canut-Rocafort, G., and Price, J.: Land Surface Interactions with the Atmosphere over the Iberian Semi-Arid Environment (LIAISE), GEWEX Newsletter, Vol. 29 No 1, Quarter 1, 2019.

Bonnet, R., Boé, J., Dayon, G., and Martin, E.: 20th century hydrometeorological reconstructions to study the multi-decadal variations of the water cycle over France, Water Resour. Res., 53, 8366-8382, 2017.

Bowling, L. C., Kane, D. L., Gieck, R. E., Hinzman, L. D., and Lettenmaier, D. P.: The role of surface storage in a low-gradient arctic watershed, Water Resour. Res., 39, https://doi.org/10.1029/2002WR001466, 2003. 
Braud, I., Varado, N., and Olioso, A.: Comparison of root water uptake modules using either the surface energy balance or potential transpiration, J. Hydrol., 301, 267-286, 2005.

Brulebois, E., Castel, T., Richard, Y., Chateau-Smith, C., and Amiotte-Suchet, P.: Hydrological response to an abrupt shift in surface air temperature over France in 1987/88, J. Hydrol., 531, 892-901, 2015

Brun E., E. Martin, V. Simon, C. Gendre C. and C. Coléou: An energy and mass model of snow cover suitable for operational avalanche forecasting, J. Glaciol., 35, 333-342, https://doi.org/10.3189/S0022143000009254, 1989

Brun, E., Martin, E., and Spiridonov, V.: The coupling of a multilayered snow model with a GCM, Ann. Glaciol., 25, 66-72, 1997.

Calvet, J.-C., Noilhan, J., Roujean, J.-L., Bessemoulin, P., Cabelguenne, M., Olioso, A., and Wigneron, J.-P.: An interactive vegetation SVAT model tested against data from six contrasting sites, Agr. Forest Meteorol., 92, 73-95, 1998.

Calvet, J.-C., Rivalland, V., Picon-Cochard, C., and Guehl, J. M.: Modelling forest transpiration and $\mathrm{co} 2$ fluxes - response to soil moisture stress, Agr. Forest Meteorol., 124, 143-156, 2004.

Carrer, D., Lafont, S., Roujean, J.-L., Calvet, J.-C., Meurey, C., Le Moigne, P., and Trigo, I. F.: Incoming solar and infrared ra- diation derived from METEOSAT: Impact on the modeled land water and energy budget over France, J. Hydrometeorol., 13, 504520, https://doi.org/10.1175/JHM-D-11-059.1, 2012.

Carrer, D., Meurey, C., Ceamanos, X., Roujean, J.-L., Calvet, J.-C., and Liu, S.: Dynamic mapping of snow-free vegetation and bare soil albedos at global $1 \mathrm{~km}$ scale from 10-year analysis of MODIS satellite products, Remote Sens. Environ., 140, 420-432, 2014.

Chen, T. H., Henderson-Sellers, A., Milly, P., Pitman, A., Beljaars, A., Polcher, J., Abramopoulos, F., Boone, A., Chang, S., Chen, F., Dai, Y., Desborough, C. E., Dickinson, R. E., Dümenil, L., Ek, M., Garratt, J. R., Gedney, N., Gusev, Y. M., Kim, J., Koster, R., Kowalczyk, E. A., Laval, K., Lean, J., Lettenmaier, D., Liang, X., Mahfouf, J.-F., Mengelkamp, H.-T., Mitchell, K., Nasonova, O. N., Noilhan, J., Robock, A., Rosenzweig, C., Schaake, J., Schlosser, C. A., Schulz, J.-P., Shao, Y., Shmakin, A. B., Verseghy, D. L., Wetzel, P., Wood, E. F., Xue, Y., Yang, Z.L., and Zeng, Q.: Cabauw experimental results from the project for intercomparison of land-surface parameterization schemes, J. Climate, 10, 1194-1215, 1997

Courtier, P. and Geleyn, J.-F.: A global spectral model with variable resolution - application to the shallow-water equations, Q. J. Roy. Meteorol. Soc., 114, 1321-1346, 1988

Dayon, G., Boé, J., Martin, E., and Gailhard, J.: Impacts of climate change on the hydrological cycle over France and associated uncertainties, Comptes Rendus Geoscience, 350, 141-153, https://doi.org/10.1016/j.crte.2018.03.001, 2018.

Decharme, B., Boone, A., Delire, C., and Noilhan, J.: Local evaluation of the Interaction between Soil Biosphere Atmosphere soil multilayer diffusion scheme using four pedotransfer functions, J. Geophys. Res.-Atmos., 116, D20126, https://doi.org/10.1029/2011JD016002, 2011.

Decharme, B., Martin, E., and Faroux, S.: Reconciling soil thermal and hydrological lower boundary conditions in land surface models, J. Geophys. Res.-Atmos., 118, 7819-7834, https://doi.org/10.1002/jgrd.50631, 2013.
Decharme, B., Brun, E., Boone, A., Delire, C., Le Moigne, P., and Morin, S.: Impacts of snow and organic soils parameterization on northern Eurasian soil temperature profiles simulated by the ISBA land surface model, The Cryosphere, 10, 853-877, https://doi.org/10.5194/tc-10-853-2016, 2016.

Decharme, B., Delire, C., Minvielle, M., Colin, J., Vergnes, J.-P., Alias, A., Saint-Martin, D., Séférian, R., Sénési, S., and Voldoire, A.: Recent changes in the ISBA-CTRIP land surface system for use in the CNRM-CM6 climate model and in global off-line hydrological applications, J. Adv. Model. Ea. Syst., 11, 1211-1252, https://doi.org/10.1029/2018MS001545, 2019.

Dirmeyer, P. A.: A history and review of the global soil wetness project (gswp), J. Hydrometeorol., 12, 729-749, 2011.

Ducharne, A., Laval, K., and Polcher, J.: Sensitivity of the hydrological cycle to the parameterization of soil hydrology in a GCM, Clim. Dynam., 14, 307-327, 1998.

Dümenil, L. and Todini, E.: A rainfall-runoff scheme for use in the Hamburg climate model, edited by: O'Kane, J. P., Advances in Theoretical Hydrology, A Tribute to James Dooge, Eur. Geophys. Soc. Ser. Hydrol. Sci., 1, Elsevier, Amsterdam (1992), pp. 129-157, 1992.

Dunne, T. and Black, R.D.: An experimental investigation of runoff production in permeable soils, Water Resour. Res., 6, 179-191, https://doi.org/10.1029/WR006i002p00478, 1970.

Durand, Y., Brun, E., Mérindol, L., Guyomarc'h, G., Lesaffre, B., and Eric, M.: A meteorological estimation of relevant parameters for snow models, Ann. Glaciol., 18, 65-71, 1993.

El Maayar, M., Chen, J. M., and Price, D. T.: On the use of field measurements of energy fluxes to evaluate land surface models, Ecol. Model., 214, 293-304, 2008.

Etchevers, P.: Modélisation de la phase continentale du cycle de l'eau à l'échelle régionale, Impact de la modélisation de la neige sur l'hydrologie du Rhône, Thesis, Université Paul Sabatier, Toulouse, France, 2000.

Etchevers, P., Martin, E., Brown, R., Fierz, C., Lejeune, Y., Bazile, E., Boone, A., Dai, Y.-J., Essery, R., Fernandez, A., Gusev, Y., Jordan, R., Koren, V., Kowalczyk, E., Nasonova, N. O., Pyles, R. D., Schlosser, A., Shmakin, A. B., Smirnova, T. G., Strasser, U., Verseghy, D., Yamazaki, T., and Yang, Z.-L.: Validation of the energy budget of an alpine snowpack simulated by several snow models (snowmip project), Ann. Glaciol., 38, 150-158, 2004.

Fang, L., Hain, C. R., Zhan, X., and Anderson, M. C.: An intercomparison of soil moisture data products from satellite remote sensing and a land surface model, Int. J. Appl. Earth Observation and Geoinformation, 48, 37-50, 2016.

Faroux, S., Kaptué Tchuenté, A. T., Roujean, J.-L., Masson, V., Martin, E., and Le Moigne, P.: ECOCLIMAP-II/Europe: a twofold database of ecosystems and surface parameters at $1 \mathrm{~km}$ resolution based on satellite information for use in land surface, meteorological and climate models, Geosci. Model Dev., 6, 563582, https://doi.org/10.5194/gmd-6-563-2013, 2013

Foken, T.: The energy balance closure: an overview, Ecol. Soc. Am., 18, 1351-1367, https://doi.org/10.1890/06-0922.1, 2008.

Goward, S. N., Xue, Y., and Czajkowski, K. P.: Evaluating land surface moisture conditions from the remotely sensed temperature/vegetation index measurements. An exploration with the simplified simple biosphere model, Remote Sens. Environ., 79, 225-242, 2000. 
Habets, F.: Modélisation du cycle continental de l'eau à l'échelle régionale: application aux bassins versants de l'Adour et du Rhône. Thèse, Université Paul Sabatier, Toulouse, France, 1998.

Habets, F., Boone, A., Champeaux, J. L., Etchevers, P., Franchisteìguy, L., Leblois, E., Ledoux, E., Le Moigne, P., Martin, E., Morel, S., Noilhan, J., Quintana Seguí, P., Rousset-Regimbeau, F., and Viennot, P.: The SAFRAN-ISBA-MODCOU hydrometeorological model applied over France, J. Geophys. Res.-Atmos., 113, D06113, https://doi.org/10.1029/2007JD008548, 2008.

Harding, R., Polcher, J., Boone, A., Ek, M., Wheater, H., and Nazemi, A.: Anthropogenic Influences on the Global Water Cycle - Challenges for the GEWEX Community, GEWEX News, 27, 6-8, 2015.

Henderson-Sellers, A., McGuffie, K., and Pitman, A.: The Project for Intercomparison of Land-surface Parametrization Schemes (PILPS): 1992 to 1995, Clim. Dynam., 12, 849-859, https://doi.org/10.1007/s003820050147, 1996.

Jarvis, P. G.: The interpretation of leaf water potential and stomatal conductance found in canopies in the field, Philos. T. Roy. Soc. London B, 273, 593-610, 1976.

Kalma, J. D., McVicar, T. R., and McCabe, M. F.: Estimating Land Surface Evaporation: A Review of Methods Using Remotely Sensed Surface Temperature Data, Surv Geophys, 29, 421-469, https://doi.org/10.1007/s10712-008-9037-z, 2008.

King, D., Burrill, A., Daroussin, J., Le Bas, C., Tavernier, R., and Van Ranst, E.: The EU soil geographic database, in: European Land Information Systems for Agro-environmental Monitoring, edited by: King, D., Jones, R. J. A., and Thomasson, A. J., JRC European Commission, ISPRA, 43-60, 1995.

Lafaysse, M., Hingray, B., Etchevers, P., Martin, E., and Obled, C.: Influence of spatial discretization, underground water storage and glacier melt on a physically-based hydrological model of the Upper Durance River basin, J. Hydrol., 403, 116-129, https://doi.org/10.1016/j.jhydrol.2011.03.046, 2011.

Le Moigne, P.: Description de l'analyse des champs de surface sur la France par le systeÌme SAFRAN, Tech. Note, 30 pp., 77, MeteoFrance/CNRM, Toulouse, France, 2002.

Le Moigne, P.: Supplement of gmd-2020-31 [Data set], Zenodo, https://doi.org/10.5281/zenodo.3685899, 2020.

Ledoux, E., Girard, G., De Marsily, G., and Deschenes, J.: Spatially distributed modelling: Conceptual approach, coupling surface water and ground-water, Unsaturated flow hydrologic modeling: theory and practice, edited by: Morel-Seytoux, H. J., 434454, NATO Sciences Service, 1989.

Lejeune, Y., Dumont, M., Panel, J.-M., Lafaysse, M., Lapalus, P., Le Gac, E., Lesaffre, B., and Morin, S.: 57 years (1960-2017) of snow and meteorological observations from a mid-altitude mountain site (Col de Porte, France, $1325 \mathrm{~m}$ of altitude), Earth Syst. Sci. Data, 11, 71-88, https://doi.org/10.5194/essd-11-712019, 2019.

Liang, X.: A Two-Layer Variable Infiltration Capacity Land Surface Representation for General Circulation Models, Water Resour. Series, TR140, 208 pp., 1994.

Lohmann, D., Raschke, E., Nijssen, B., and Lettenmaier, D. P.: Regional scale hydrology, Part II: Application of the VIC-2L model to the Weser River, Germany, Hydrol. Sci. J., 43, 143-158, 1998.

Long, D., Longuevergne, L., and Scanlon, B. R.: Uncertainty in evapotranspiration from land surface modeling, remote sens- ing, and GRACE satellites, Water Resour. Res., 50, 1131-1151, https://doi.org/10.1002/2013WR014581, 2014.

Luo, L., Robock, A., Vinnikov, K., Schlosser, C. A., Slater, A., Boone, A., Braden, H., Cox, P., de Rosnay, P., Dickinson, R., Dai, Y.-J., Duan, Q., Etchevers, P., HendersonSellers, A., Gedney, N., Gusev, Y., Habets, F., Kim, J., Kowalczyk, E., Mitchell, K., Nasonova, O., Noilhan, J., Pitman, A., Schaake, J., Shmakin, A., Smirnova, T., Wetzel, P., Xue, Y., Yang, Z.-L., and Zeng, Q.-C.: Effects of frozen soil on soil temperature, spring infiltration, and runoff: Results from the PILPS 2(d) experiment at Valdai, Russia, J. Hydrometeorol., 4, 334-351, https://doi.org/10.1175/15257541(2003)4<334:EOFSOS>2.0.CO;2, 2003.

Mahfouf, J.-F. and Noilhan, J.: Inclusion of gravitational drainage in a land surface scheme based on the force-restore method, J. Appl. Meteorol., 35, 987-992, 1996.

Martin E., Gascoin, S., Grusson, Y., Murgue, C., Bardeau, M., Anctil, F., Ferrant, S., Lardy, R., Le Moigne, P., Leenhardt, D., Rivalland, V., Sánchez Pérez, J.-M., Sauvage, S., and Therond, O.: On the Use of Hydrological Models and Satellite Data to Study the Water Budget of River Basins Affected by Human Activities: Examples from the Garonne Basin of France, Surv. Geophys., 37, 223-247, https://doi.org/10.1007/s10712-016-9366-2, 2016.

Masson, V., Champeaux, J. L., Chauvin, F., Meriguet, C., and Lacaze, R.: A global data base of land surface parameters at $1 \mathrm{~km}$ resolution in meteorological and climate models, J. Climate, 16, 1261-1282, 2003.

Masson, V., Le Moigne, P., Martin, E., Faroux, S., Alias, A., Alkama, R., Belamari, S., Barbu, A., Boone, A., Bouyssel, F., Brousseau, P., Brun, E., Calvet, J.-C., Carrer, D., Decharme, B., Delire, C., Donier, S., Essaouini, K., Gibelin, A.-L., Giordani, H., Habets, F., Jidane, M., Kerdraon, G., Kourzeneva, E., Lafaysse, M., Lafont, S., Lebeaupin Brossier, C., Lemonsu, A., Mahfouf, J.-F., Marguinaud, P., Mokhtari, M., Morin, S., Pigeon, G., Salgado, R., Seity, Y., Taillefer, F., Tanguy, G., Tulet, P., Vincendon, B., Vionnet, V., and Voldoire, A.: The SURFEXv7.2 land and ocean surface platform for coupled or offline simulation of earth surface variables and fluxes, Geosci. Model Dev., 6, 929-960, https://doi.org/10.5194/gmd-6-929-2013, 2013.

Morin, S., Lejeune, Y., Lesaffre, B., Panel, J.-M., Poncet, D., David, P., and Sudul, M.: An 18-yr long (1993-2011) snow and meteorological dataset from a mid-altitude mountain site (Col de Porte, France, $1325 \mathrm{~m}$ alt.) for driving and evaluating snowpack models, Earth Syst. Sci. Data, 4, 13-21, https://doi.org/10.5194/essd4-13-2012, 2012.

Nachtergaele, F., Velthuizen, H., Verelst, L., and Wiberg, D.: Harmonized World Soil Database Version 1.2, FAO/IIASA/ISRIC/ISS-CAS/JRC, 2012.

Napoly, A.: Apport de paramétrisations avancées des processus liés à la végétation dans les modèles de surface pour la simulation des flux atmosphériques et hydrologiques, Thesis, Université Paul Sabatier, Toulouse, France, 2016.

Napoly, A., Boone, A., Samuelsson, P., Gollvik, S., Martin, E., Seferian, R., Carrer, D., Decharme, B., and Jarlan, L.: The interactions between soil-biosphere-atmosphere (ISBA) land surface model multi-energy balance (MEB) option in SURFEXv8 Part 2: Introduction of a litter formulation and model evaluation for local-scale forest sites, Geosci. Model Dev., 10, 1621-1644, https://doi.org/10.5194/gmd-10-1621-2017, 2017. 
Nash, J. E. and Sutcliffe, J. V.: (1970) River Flow Forecasting through Conceptual Model. Part 1A Discussion of Principles, J. Hydrol., 10, 282-290, https://doi.org/10.1016/00221694(70)90255-6, 2012.

Noilhan, J. and Lacarrere, P.: GCM grid-scale evaporation from mesoscale modeling, J. Climate, 8, 206-223, 1995.

Noilhan, J. and Mahfouf, J.-F.: The ISBA land surface parameterization scheme, Global Planet. Change, 13, 145-159, 1996.

Noilhan, J. and Planton, S.: A Simple Parameterization of Land Surface Processes for Meteorological Models, Mon. Weather Rev., 117, 536-549, https://doi.org/10.1175/15200493(1989)117<0536:ASPOLS>2.0.CO;2, 1989.

Overgaard, J., Rosbjerg, D., and Butts, M. B.: Land-surface modelling in hydrological perspective - a review, Biogeosciences, 3, 229-241, https://doi.org/10.5194/bg-3-229-2006, 2006.

Pitman, A., Henderson-Sellers, A., Abramopoulos, F., Avissar, R., Bonan, G., Boone, A., Cogley, J., Dickinson, R., Ek, M., Entekhabi, D., Flamiglietti, J., Garratt, J. R., Frech, M., Hahmann, A., Koster, R., Kowalczyk, E. A., Laval, K., Lean, L., Lee, T. J., Lettenmaier, D., Liang, X., Mahfouf, J. -F., Mahrt, L., Milly, M. C. D., Mitchell, K., de Noblet, N., Noilhan, J., Pan, H., Pielke, R., Robock, A., Rosenzweig, C., Running, C., Schlosser, A., Scott, R., Suarez, M., Thompson, S., Verseghy, D. L., Wetzel, P., Wood, E. F., Xue, Y., Yang, Z. L., and Zhang L.: Project for intercomparison of land-surface parameterization schemes (pilps): results from off-line control simulations (phase 1a), Inter GEWEX Project Office Publ., in: GEWEX IGPO publication series, 7, 1993.

Quéno, L., Karbou, F., Vionnet, V., and Dombrowski-Etchevers, I.: Satellite-derived products of solar and longwave irradiances used for snowpack modelling in mountainous terrain, Hydrol. Earth Syst. Sci., 24, 2083-2104, https://doi.org/10.5194/hess-24-20832020, 2020.

Quintana Seguí, P., Le Moigne, P., Durand, Y., Martin, E., Habets, F., Baillon, M., Canellas, C., Franchisteguy, L., and Morel, S.: Analysis of Near-Surface Atmospheric Variables: Validation of the SAFRAN Analysis over France, J. Appl. Meteor. Climatol., 47, 92-107, 2008.

Ritter, B. and Geleyn, J.-F.: A comprehensive radiation scheme for numerical weather prediction models with potential applications in climate simulations, Mon. Weather Rev., 120, 303-325, 1992.

Sauter, T. and Obleitner, F.: Assessing the uncertainty of glacier mass-balance simulations in the European Arctic based on variance decomposition, Geosci. Model Dev., 8, 3911-3928, https://doi.org/10.5194/gmd-8-3911-2015, 2015.

Schlosser, C. A., Slater, A. G., Robock, A., Pitman, A. J., Vinnikov, K. Y., Henderson-Sellers, A., Speranskaya, N. A., and Mitchell, K.: Simulations of a boreal grassland hydrology at valdai, russia: Pilps phase 2 (d), Mon. Weather Rev., 128, 301-321, 2000.

Schmugge, T. J., Kustas, W. P., Ritchie J. C., Jackson, T. J., and Rango, A.: Remote sensing in hydrology, Adv. Water Res., 25, 1367-1385, 2002.

Seity, Y., Brousseau, P., Malardel, S., Hello, G., Bénard, P., Bouttier, F., Lac, C., and Masson, V.: The AROME-France ConvectiveScale Operational Model, Mon. Weather Rev., 139, 976-999, https://doi.org/10.1175/2010MWR3425.1, 2011.

Sellers, P., Dickinson, R., Randall, D., Betts, A., Hall, F., Berry, J., Collatz, G., Denning, A., Mooney, H., Nobre, C., Sato, N., Field, C. B., and Henderson-Sellers, A.: Modeling the exchanges of en- ergy, water, and carbon between continents and the atmosphere, Science, 275, 502-509, 1997.

Taylor, K. E.: Summarizing multiple aspects of model performance in a single diagram, J. Geophys. Res., 106, 7183-7192, 2001.

Trigo, I. F., DaCamara, C. C., Viterbo, P., Roujean, J.-L., Olesen, F., Barroso, C., Camacho-de Coca, F., Carrer, D., Freitas, S. C., García-Haro, J., Geiger, B., Gellens-Meulenberghs, F., Ghilain, N., Meliá, J., Pessanha, L., Siljamo, N., and Arboleda, A.: The Satellite Application Facility on Land Surface Analysis, Int. J. Remote Sens., 32, 2725-2744, https://doi.org/10.1080/01431161003743199, 2011.

Uppala, S. M., Kållberg, P. W., Simmons, A. J., Andrae, U., Da Costa Bechtold, V., Fiorino, M., Gibson, J. K., Haseler, J., Hernandez, A., Kelly, G. A., Li, X., Onogi, K., Saarinen, S., Sokka, N., Allan, R. P., Andersson, E., Arpe, K., Balmaseda, M. A., Beljaars, A. C. M., Van De Berg, L., Bidlot, J., Bormann, N., Caires, S., Chevallier, F., Dethof, A., Dragosavac, M., Fisher, M., Fuentes, M., Hagemann, S., Hólm, E., Hoskins, B. J., Isaksen, L., Janssen, P. A. E. M., Jenne, R., McNally, A. P., Mahfouf, J. F., Morcrette, J.-J., Rayner, N. A., Saunders, R. W., Simon, P., Sterl, A., Trenberth, K. E., Untch, A., Vasiljevic, D., Viterbo, P., and Woollen, J.: The ERA-40 re-analysis, Q. J. Roy. Meteorol. Soc., 131, 2961-3012, 2005.

Vergnes, J.-P., Decharme, B., and Habets, F.: Introduction of groundwater capillary rises using subgrid spatial variability of topography into the ISBA land surface model, J. Geophys. Res.-Atmos., 119, 11065-11086, https://doi.org/10.1002/2014JD021573, 2014.

Vergnes, J.-P., Roux, N., Habets, F., Ackerer, P., Amraoui, N., Besson, F., Caballero, Y., Courtois, Q., de Dreuzy, J.-R., Etchevers, P., Gallois, N., Leroux, D. J., Longuevergne, L., Le Moigne, P., Morel, T., Munier, S., Regimbeau, F., Thiéry, D., and Viennot, P.: The AquiFR hydrometeorological modelling platform as a tool for improving groundwater resource monitoring over France: evaluation over a 60 -year period, Hydrol. Earth Syst. Sci., 24, 633-654, https://doi.org/10.5194/hess-24633-2020, 2020

Vidal, J.-P., Martin, E., Franchistéguy, L., Habets, F., Soubeyroux, J.-M., Blanchard, M., and Baillon, M.: Multilevel and multiscale drought reanalysis over France with the Safran-Isba-Modcou hydrometeorological suite, Hydrol. Earth Syst. Sci., 14, 459-478, https://doi.org/10.5194/hess-14-459-2010, 2010.

Vionnet, V., Brun, E., Morin, S., Boone, A., Faroux, S., Le Moigne, P., Martin, E., and Willemet, J.-M.: The detailed snowpack scheme Crocus and its implementation in SURFEX v7.2, Geosci. Model Dev., 5, 773-791, https://doi.org/10.5194/gmd-5773-2012, 2012.

Voirin, S., Calvet, J.-C., Habets, F., and Noilhan, J.: Interactive vegetation modeling at a regional scale: application to the Adour basin, Phys. Chem. Earth (B), 26, 479-484, 2001.

Wang, S., Pan, M., Mu, Q., Shi, X., Mao, J., Brümmer, C., Jassal, R. S., Krishnan, P., Li, J., and Black, T. A.: Comparing Evapotranspiration from Eddy Covariance Measurements, Water Budgets, Remote Sensing, and Land Surface Models over Canada, J. Hydrometeorol., 16, 1540-1560, 2015.

Wild, M.: Enlightening global dimming and brightening, B. Am. Meteorol. Soc., 93, 27-37, 2012.

Wood, E. F., Lettenmaier, D. P., Liang, X., Lohmann, D., Boone, A., Chang, S., Chen, F., Dai, Y., Dickinson, R. E., Duan, Q., Ek, 
M., Gusev, Y. M., Habets, F., Irannejad, P., Koster, R., Mitchel, K. E., Nasonova, O. N., Noilhan, J., Schaake, J., Schlosser, A., Shao, Y., Shmakin, A. B., Verseghy, D., Warrach, K., Wetzel, P., Xue, Y., Yang, Z.-L., and Zeng, Q.-C.: The project for intercomparison of land-surface parameterization schemes (pilps) phase 2 (c) red-arkansas river basin experiment: 1. experiment description and summary intercomparisons, Global Planet. Change, 19, 115-135, 1998. 